\title{
Bankalarda Finansal Kırılganlığı Etkileyen Faktörlerin Panel Veri Analizi ile Belirlenmesi
}

Bankalarda Finansal Kırılganlığı Etkileyen Faktörlerin Panel Veri Analizi ile Belirlenmesi

Öz

Çalışmada, Türkiye bankacılık sektöründe 2002-2015 döneminde devamlı olarak faaliyet gösteren ticaret bankalarının finansal kırılganlıklarına etki eden mikro faktörlerin ortaya çıkarılması amaçlanmıştır. Finansal kırılganlık, takipteki kredi oranı ve sermaye yeterlilik rasyosu ile temsil edilirken; mikro faktörler ise aktif karlılık oranı, özsermaye karlılığı, likidite oranı, banka büyüklüğü, finansal kaldıraç ve net faiz marjı ile temsil edilmiştir. Finansal kırılganlığa etki eden faktörlerin tespit edilebilmesi için iki ayrı model oluşturulmuştur. Bu modeller panel veri yöntemi ile analiz edilmiştir. Analiz neticesinde, model 1'de takipteki kredi oranı ile banka büyüklüğü arasında anlamlı ve negatif ilişki tespit edilirken; likidite oranı ile anlamlı ve pozitif ilişki tespit edilmiştir. Model 2'de ise sermaye yeterlilik oranı ile net faiz marjı ve aktif karlılık oranı arasında anlamlı ve pozitif ilişki belirlenirken; finansal kaldıraç ve özsermaye karlılığı ile anlamlı ve negatif ilişki belirlenmiştir.

Anahtar Kelimeler: Finansal Kırılganlık, Banka, Panel Veri Analizi

\section{Giriş}

Finansal serbestleşme, ticaret hacmi, finansal piyasalar gibi ekonominin her alanında dönüşüm yaşanmasına ve finansal sistemin büyümesine yol açmıştır. Finansal sistemde gerçekleşen bu büyüme ile finansal kırılganlık olgusu önem kazanmıştır. Finansal kırılganlık, piyasalarda gerçekleşebilecek küçük çapta şokların ekonomiyi, büyük çapta finansal krizlerin içerisine çekebilecek aşırı düzeyde duyarlılığa sahip bir durum olarak ifade edilebilmektedir (Allen ve Gale, 2004: 1015). Diğer bir ifadeyle finansal kırılganlık, finansal sistem içerisinde gerçekleşebilecek küçük çapta ve rutin denilebilecek şokların neden olduğu büyük ölçekli finansal krizlere karşı olan duyarlılık olarak tanımlanabilmektedir (Lagunoff ve Schreft, 2001: 220).

Finansal kırılganlık, piyasalarda istikrarsızlığa neden olabilmekte ve ekonomiyi olumsuz yönde etkileyebilmektedir. Finansal piyasaların en önemli aktörlerinden biri konumunda olan bankacılık sisteminde de finansal serbestleşme sonrasında spekülatif finansal işlemler, finansal

\footnotetext{
${ }^{1}$ Arş. Gör. Dr., Şırnak Üniversitesi, iiBF, İşletme Bölümü, emresatopal@ hotmail.com, http://orcid.org/0000-0001-8771$779 \mathrm{X}$
} 
araç sayısı ve sermaye hareketleri artmakta, bu durumlar da bankacılık sisteminin işleyişinde hassasiyet oluşturmaktadır. Bu hassasiyet durumu da finansal kırılganlıkla birlikte finansal krizlerin ortaya çıkmasına neden olabilmektedir (Grabel, 1997: 111).

Finansal krizlerin temelindeki sistemik risklerin belirlenmesi, bankacılık sisteminde ve ekonominin genelinde olası kırılganlıkların kontrol edilebilmesi açısından önemlidir. Finansal olarak kırılgan bir yapı, bankacılık sistemini zayıflatabilmekte, dışsal şoklara karşı finansal sistemi ve ekonomiyi savunmasız bırakabilmekte, piyasalarda ve ekonomide dengesizliklere yol açabilmektedir. Dolayısıyla, finansal sistem içerisinde olası finansal krizlerin etkilerini en aza indirebilmek için erken uyarı mekanizması olarak görülebilen finansal kırılganlığın ölçülmesi ve finansal kırılganlığı etkileyen mikro ve makro düzeyde faktörlerin belirlenmesi önem arz etmektedir. Finansal kırılganlığa neden olan faktörlerin tespit edilmesi, finansal krizlerin ve ekonomik durağanlığın olumsuz etkilerinin minimize edilebilmesi açısından bir gösterge konumundadır.

Çalışmada, bankaların finansal kırılganlıklarına mikro düzeyde etki eden, diğer bir deyişle bankalara özgü faktörleri belirlemek amaçlanmıştır. Bu bağlamda, öncelikle finansal kırılganlık kavramına genel olarak değinilmiş ve konuya ilişkin gerçekleştirilen önceki çalışmaların yer aldığı literatür taramasına yer verilmiştir. Sonrasında ise 2002-2015 döneminde Türkiye bankacılık sisteminde devamlı olarak faaliyet gösteren 20 ticaret bankası analiz kapsamında incelenmiştir. Finansal kırılganlığa etki eden mikro düzeyde faktörlerin belirlenebilmesi için panel veri analizlerinden faydalanılmıştır. Analiz neticesinde bankaların finansal kırılganlıklarına etki eden faktörler tespit edilmiştir. Bu doğrultuda çalışma, finansal kırılganlığın makro düzeyde sermaye yeterlilik oranı ile mikro düzeyde ise takipteki kredi oranı ile ayrı ayrı ölçülmesi ve finansal kırılganlığa etki ettiği düşünülen bankaya özgü faktörlerin bankaların finansman kararları, likidite, faiz politikaları, karlııı durumları ve banka büyüklüğü esas alınarak belirlenmesi açısından özgün bir değere sahip olmakta ve ulusal literatüre katkı sağlamaktadır.

\section{Finansal Kırılganlığa iliş̧kin Literatür}

Zwet ve Swank (2000), finansal kırılganlık ile makroekonomik performans arasındaki ilişkinin incelendiği çalışma, gelişmiş ve gelişmekte olan ülkelerin 1980-1998 dönemindeki verilerini kapsamaktadır. Çalışmada, makroekonomik faktörlerin finansal kırılganlığı pozitif yönde etkilediği ve bu etkinin gelişmekte olan ülkelerde daha önemli olduğu ortaya çıkarılmıştır.

Ghosh (2010) tarafından yapılan çalışmada, 1996-2008 döneminde Hindistan bankacılık sektöründe faaliyet gösteren bankaların kredi büyümesi, banka istikrarı ve finansal kırılganlık arasındaki ilişki incelenmiştir. Analiz sonucunda hızlı bir şekilde büyüyen kredi hacminin içerdiği potansiyel riskleri en aza indirebilmek için bankaların finansal kırılganlıklarını azaltabilmek ve istikrarı sağlayabilmek için risk bazlı denetime öncelik verilmesi gerektiği tespit edilmiştir.

Penas ve Alkan (2010) tarafından yapılan çalışmada, bankaların kötüleşen finansal kırılganlık göstergelerinin 2000/2001 döneminde finansal krizin gerçekleşmesinde etkisinin olup olmadığı araştırılmıştır. Ayrıca çalışmada piyasa aktarılan bilgilerin kalitesi ve zamanlamasına karşı piyasanın nasıl tepki verdiği de incelenmiştir. Çalışma neticesinde, finansal kırılganlık göstergesi olan vade uyumsuzluğu, döviz-yerli para uyumsuzluğu ve takipteki kredi oranında herhangi bir artış söz konusu olduğunda, banka pay sahiplerinin gelecekteki kazançları doğrultusunda bu durumlara negatif yönde tepki verdikleri tespit edilmiştir. Ayrıca, denetim raporlarının açıklanmasında gecikme yaşanması, bilgi aktarımını engellemekte ve dolayısıyla aktarımın zamanlamasının iyileştirilmesi gerekliliği de ortaya koyulmuştur. Son olarak çalışmada, menkul kıymet fiyatlarının 
finansal kırılganlık göstergelerine verdikleri tepkilerin, bankaların mali yapısının sağlamlığı ve güvenliği için yeterli düzeyde bir etkiye sahip olmadığı da belirlenmiştir.

Bruno, Cartapanis ve Nasica (2013) çalışmalarında, bankaların bilanço ve kaldıraç oranlarına etki eden dinamiklerin belirlenmesi ve bu belirleyicilerin finansal kırılganlık üzerindeki etkileri analiz edilmiştir. Analiz sonucunda, finansal kırılganlığı minimize eden bir kaldıraç değerinin varlığı tespit edilirken, bu değerin bankaların genel iş ortamına, teminatların beklenen değerine ve risksiz faiz oranına bağlı olduğu da tespit edilmiştir. Bu bulguların, Basel 3'te yer alan sabit kaldıraç oran yerine, ekonomik koşullara bağı olarak ayarlanabilir kaldıraç oranının oluşturulmasını destekler nitelikte olduğunu ortaya koymaktadır.

Fielding ve Rewilak (2015), 1999-2011 döneminde 121 ülkeden 956 bankanın incelendiği çalışmada, aşırı düzeyde kredi verilmesi, finansal kırılganlık ve bankacılık krizleri arasındaki ilişki analiz edilmiştir. Analiz sonucunda sermaye girişlerinde ve kredi tahsislerindeki dalgalanmaların bankacılık krizlerini ortaya çıkarma olasılıklarını artırdığı belirlenmiştir. Ayrıca çalışmada finansal kırılganlığın yüksek düzeyde olduğu bankacılık sistemlerinde bu dalgalanmaların ve kırılganıı̆ın olası krizlerin yaşanma ihtimalini artırdığı ortaya çıkarılmıştır.

Iftikhar (2015), finansal reformlar, finansal liberalizasyon ve bankacılık düzenlemesinin kalitesi ile mali kırılganlık denetimi arasındaki ilişki araştırmıştır. Çalışmada, bankacılık sektörünün finansal açıdan kırılganlığı, yalnızca bankaya özgü ve makro-spesifik değişkenler tarafından değil, aynı zamanda finansal liberalizasyon ve bankacılık düzenlemeleri ve denetim politikaları ile de ilgili olduğu ortaya çıkarılmıştır. Çalışmanın ampirik sonuçlarına göre ise, finansal reformların ve finansal liberalizasyonun finansal kırılganlığı artırdığı, buna karşın güçlü bankacılık düzenlemeleri ve denetiminin ise finansal kırılganlığı azalttığı bulgulanmıştır. Buna ek olarak, kredilerdeki gecikme uzunluğunun artmasının, finansal kırılganlığı pozitif yönde etkilediği, özsermaye karlılığı ve toplam varlıkların büyüklüğünün ise finansal kırılganlığı negatif yönde etkilediği belirlenmiştir.

Klomp ve Haan (2015), 2002-2008 yılları arasında gelişmiş ve gelişmekte olan 94 ülkeden 1238 bankayı çalışma kapsamında incelemiştir. Çalışmada, bankaların finansal kırılganlıklarına etki eden bankacılık düzenleme ve denetleme faaliyetlerinin, bankaların yapısına bağlı olarak değişip değişmediği araştırılmıştır. Çalışma sonucunda, düzenleme ve denetleme faaliyetlerinin sıkılaşmasının, finansal kırılganlığı azalttığı tespit edilmiştir. Ayrıca çalışmada, sermaye yeterliliğinin ve gözetimsel kontrolün artması sonucunda bankacılıkta riskin azaldığı da ortaya çıkarılmıştır. Bununla birlikte, düzenleme ve denetleme faaliyetlerinin etkisinin, bankaların organizasyon yapısına bağı olduğu da belirlenmiştir.

Kinda, Mlachila ve Ouedraogo (2016), emtia fiyatlarında yaşanan şokların finansal sektörün kırılganlığına olan etkisini ortaya çıkarmayı hedeflemişlerdir. Bu bağlamda 1997-2013 döneminde gelişmiş ve gelişmekte olan 71 ülkenin ekonomileri analiz edilmiştir. Analiz neticesinde, emtia fiyatlarında yaşanan olumsuz şokların finansal sektörü zayıflatma eğilimi gösterdiği ve daha büyük şokların daha belirgin etkilere sahip olduğu tespit edilmiştir. Ayrıca, banka karlılığının, likiditesinin ve takipteki krediler için ayrılan karşılıkların düştüğü dönemlerde emtia fiyatlarındaki olumsuz şokların, finansal kırılganlığı ve krizlerin ortaya çıkma olasılığını etkilediği belirlenmiştir.

Korkmaz, Erer ve Erer (2016) çalışmalarında, bankacılık sektöründeki yoğunlaşma ile finansal kırılganlık arasındaki ilişkiyi incelemişlerdir. Bu bağlamda 2007-2014 yılları arasında Türkiye'de faaliyet gösteren 19 bankanın finansal kırılganlı̆̆ına etki eden faktörlerin belirlenmesi 
amaçlanmıştır. Çalışma neticesinde, yoğunlaşma ile finansal kırılganlık arasında anlamlı bir ilişki bulunamazken, sermaye yeterliliğinin finansal kırılganlığı belirleyici bir unsur olduğu tespit edilmiştir. Diğer taraftan nedensellik analiz sonucuna göre ise Türkiye bankacılık sisteminde yoğunlaşma ile kırılganlık arasında çift yönlü bir etkinin varlığı tespit edilmiştir.

Egan, Hortaçsu ve Matvos (2017) tarafından yapılan çalışmada, Amerika Birleşik Devletleri bankacılık sektöründe faaliyet gösteren bankaların mevduat toplama rekabetleri ile finansal başarısızlıkları arasındaki ilişkiyi incelemişlerdir. Çalışma sonucunda \%18'in altında sermaye ihtiyacı olan bankaların sistemde önemli istikrarsızlığa ve finansal kırılganlığa neden olduğu tespit edilmiştir.

\section{Analiz}

Çalışmanın bu bölümünde finansal kırılganlığa etki eden mikro faktörlerin diğer bir ifadeyle banka içi unsurların belirlenmesine yönelik gerçekleştirilen analizler ve elde edilen bulgulara yer verilmektedir.

\subsection{Veri Seti ve Tanımlayıcı İstatistikler}

Çalışmada, bankaların finansal kırılganlıklarına mikro düzeyde etki eden faktörleri belirlemek hedeflenmiştir. Bu bağlamda 2002-2015 döneminde faaliyet gösteren 20 ticaret bankası analiz kapsamında incelenmiştir. İlgili dönemde sürekli olarak faaliyet gösteren ve verilerine tam olarak ulaşılabilen bankalar analize dâhil edilmiştir. Araştırma kapsamında incelenen bankalar, Tablo 1'de gösterilmektedir.

Tablo 1: Araştırma Kapsamında incelenen Bankalar

\begin{tabular}{clll}
\hline 1. & Akbank & 11. & ICBC Turkey Bank \\
2. & Alternatifbank & 12. & Şekerbank \\
3. & Anadolubank & 13. & Turkish Bank \\
4. & Arap Türk Bankası & 14. & Türk Ekonomi Bankası \\
5. & Bank Mellat & 15. & Türkiye Cumhuriyeti Ziraat Bankası \\
6. & Citybank & 16. & Türkiye Garanti Bankası \\
7. & Denizbank & 17. & Türkiye Halk Bankası \\
8. & Finans Bank & 18. & Türkiye İ̧̧ Bankası \\
9. & Habipbank & 19 & Türkiye Vakıflar Bankası \\
10. & HSBC Bank & 20. & Yapı ve Kredi Bankası \\
\hline
\end{tabular}

Kaynak: www.tbb.org.tr

Çalışmada, finansal kırılganlığın göstergesi olarak takipteki krediler/toplam krediler ve sermaye yeterlilik rasyosu esas alınmıştır. Finansal kırılganlığa etki ettiği düşünülen diğer değişkenler ise aktif karlılık oranı, özsermaye karlılığı, likidite, banka büyüklüğü, finansal kaldıraç ve net faiz marjı olarak belirlenmiştir. Çalışmada kullanılan değişkenlerin belirlenmesinde, Suarez (1998), Corsetti, Pesenti ve Roubini (2001), Ahumada ve Budnevich (2002), Penas ve Alkan (2010), Kinda vd. (2012), Iftikhar (2015), Bostandzic (2016) ve Korkmaz vd. (2016) tarafından yapılan çalışmalardan faydalanılmıştır. Değişkenlere ilişkin veriler, www.bddk.org.tr ve www.tbb.org.tr veri tabanlarından elde edilmiştir. Çalışmada kullanılan değişkenler ve hesaplanma şekilleri Tablo 2'de gösterilmektedir. 
Tablo 2: Değişkenler ve Hesaplama Şekilleri

\begin{tabular}{cll}
\hline $\begin{array}{c}\text { Bağımlı Değişkenler } \\
\text { (Finansal Kırılganlık) }\end{array}$ & Takipteki Kredi Oranı & Takipteki Krediler / Toplam Krediler \\
$\begin{array}{c}\text { Bağımsız Değişkenler } \\
\text { (Mikro Faktörler) }\end{array}$ & ROA & Özkaynak / (KRET+PRET+ORET)*100 \\
& ROE & Net Kar / Toplam Varlıklar \\
& Likidite & Net Kar /Toplam Özkaynak \\
& Banka Büyüklüğg̈ & Likit Varlıklar / Mevduat \\
& Finansal Kaldıraç & Toplam Aktif Doğal Logaritması \\
& Net Faiz Marıı & Mevduat / Toplam Varlıklar \\
\hline
\end{tabular}

Çalışmada kullanılan değişkenleri ve hesaplama şekillerini açıkladıktan sonra, bağımlı ve açıklayıcı değişkenlere ait tanımlayıcı istatistiki değerler hesaplanmıştır. Bu değerler, Tablo 3'te gösterilmektedir.

Tablo 3: Tanımlayıcı Istatistikler

\begin{tabular}{lcccccccc}
\hline & $\underline{\text { TKO }}$ & $\underline{\text { SYO }}$ & $\underline{\text { BUY }}$ & $\underline{\underline{\text { FIKD }}}$ & $\underline{\underline{\text { LKDT}}}$ & $\underline{\underline{\text { NFM }}}$ & $\underline{\text { ROA }}$ & $\underline{\underline{\text { ROE }}}$ \\
Ortalama & 0.074 & 24.632 & 22.944 & 0.585 & 0.171 & 0.104 & 0.017 & 0.130 \\
Medyan & 0.039 & 16.840 & 23.250 & 0.620 & 0.129 & 0.095 & 0.016 & 0.131 \\
Maksimum & 1.155 & 109.150 & 26.436 & 0.878 & 6.909 & 0.428 & 0.062 & 0.617 \\
Minimum & 0.000 & 0.000 & 17.056 & 0.028 & 0.005 & 0.022 & -0.125 & -1.786 \\
Std. Sap. & 0.136 & 18.930 & 2.218 & 0.174 & 0.434 & 0.047 & 0.014 & 0.144 \\
Çarpıklık & 5.037 & 2.304 & -0.586 & -1.453 & 13.765 & 2.402 & -3.356 & -8.044 \\
Basıklık & 32.629 & 8.027 & 2.654 & 4.851 & 209.132 & 13.646 & 40.874 & 110.959 \\
Gözlem & 280 & 280 & 280 & 280 & 280 & 280 & 280 & 280 \\
\hline
\end{tabular}

Tabloda; Takipteki Kredi Oranı (TKO), Sermaye Yeterlilik Oranı (SYO), Finansal Kaldıraç Oranı (FIKD), Banka Büyüklüğü (BUY), Net Faiz Marjı (NFM), Likidite Oranı (LKDT), Aktif Karlılık Oranı (ROA) ve Özsermaye Karlıı̆ı (ROE) ile gösterilmektedir.

Tanımlayıcı istatistik sonuçları değerlendirildiğinde, bankalarda finansal kırılganlığın göstergesi konumunda olan takipteki kredi oranının ortalama değerinin 0.07 olduğu görülmektedir. Illgili dönemde bankacılık sektöründe faaliyet gösteren bankaların vermiş oldukları kredilerin temerrüde düşme ve geri ödenmeme olasılıklarının düşük düzeyde olduğu söylenebilir. Finansal kırılganlığın bir diğer göstergesi olan sermaye yeterlilik rasyosuna ilişkin ortalama değer ise 24.63 olarak hesaplanmıştır. Basel II kritelerine göre asgari sermaye yeterlilik rasyosunun minimum \%8 olarak kabul edildiği dikkate alındığında, Türkiye bankacılık sektörünün bu oranın çok üzerinde sermaye yeterliliğine sahip olduğu söylenebilir. Bu durum yerel ve küresel finansal krizler sonrasında bankaların riski en aza indirebilmek için ihtiyatlı davranmalarından kaynaklanmaktadır. Diğer değişkenlere ilişkin ortalama değerler incelendiğinde, banka büyüklüğünün 22.94, finansal kaldıraç oranının 0.58, likidite oranının 0.17, net faiz marjının 0.10, aktif karlılık oranının 0.01 ve özsermaye karlıı̆ı̆ının ise 0.13 olduğu tespit edilmiştir. Standart sapma açısından değişkenlere ilişkin istatistiki değerler dikkate alındığında, sermaye yeterlilik rasyosunda değişkenliğin daha fazla olduğunu söylemek mümkündür. Bu değişkenlik, sektörde faaliyet gösteren bankaların büyüklüklerinin, finansman politikalarının ve sahiplik yapılarının birbirlerinden farklı olmasından kaynaklanabilmektedir. 


\subsection{Model}

Çalışmada, bankaların finansal kırılganlıkları ile finansal kırılganlığa etki eden bankalara özgü faktörler arasındaki ilişkinin belirlenmesi amacıyla model oluşturulmuştur. Finansal kırılganlık, takipteki kredi oranı ve sermaye yeterlilik rasyosu ile temsil edilebilmektedir. Finansal kırılgan।ığı etkilediği düşünülen firmalara özgü faktörler ise aktif karlılık oranı, özsermaye karlılığı, likidite, banka büyüklüğü, finansal kaldıraç ve net faiz marjı olarak belirlenmiştir. Çalışma modeli, Suarez (1998), Pesenti ve Roubini (2001), Ahumada ve Budnevich (2002), Penas ve Alkan (2010), Kinda vd. (2012), Iftikhar (2015), Bostandzic (2016) ve Korkmaz vd. (2016) tarafından yapılan çalışmalardaki modeller esas alınarak oluşturulmuştur. Çalışmada kullanılan değişkenler doğrultusunda, aşağıdaki ekonometrik modeller elde edilmiştir.

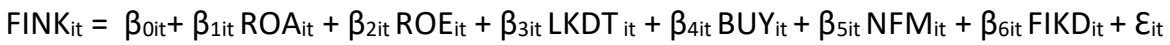

$\mathrm{SYO}_{i t}=\beta_{0 i t}+\beta_{1 i t} R A_{i t}+\beta_{2 i t} R O E_{i t}+\beta_{3 i t} L_{K D T} i t+\beta_{4 i t} B U Y_{i t}+\beta_{5 i t} N F M_{i t}+\beta_{6 i t} F_{K K D_{i t}}+\varepsilon_{i t}$

Denklemlerde, $i=1,2,3, \ldots \ldots . . N$ yatay kesit birimlerini ifade ederken, $t=1,2,3, \ldots . . . T$ zaman boyutunu, $\varepsilon$ ise panel hata terimini ifade etmektedir.

\subsection{Yöntem}

Çalışmada, öncelikle bağımsız değişkenler arasında çoklu doğrusal bağlantı sorununun olup olmadığına yönelik olarak spearman korelasyon analizi ve varyans şişirme testi gerçekleştirilmiştir. Sonrasında ise paneli oluşturan yatay kesitler (bankalar) arasındaki bağımlılık, panel ve değişken bazında Breusch-Pagan (1980) (Lagrange Multiplier-LM) ve Pesaran (2004) (Cross-section Dependence-CD) testleriyle incelenmiştir. Değişkenlerin katsayılarının yatay kesitler arasındaki değişkenliği ise Pesaran ve Yamagata (2008) tarafından geliştirilen Homogeneity Testi ile araştırılmıştır. Homojenlik sınaması, değişken bazında ve açıklayıcı değişkenler haricinde kalan sabit terimlerin yani $\alpha^{\prime}$ nın ve her bir değişkenin $\beta^{\prime} \operatorname{sının~(bağımlı~değişkene~etkisi)~homojen~}$ ya da heterojen olup olmadığına göre ayrı ayrı incelenmiştir. Serilere ilişkin durağanlık, yatay kesit bağımlılı̆ını dikkate alan Bai ve Ng (2004) PANiC ikinci nesil birim kök testi ve homojenliği/heterojenliği dikkate alan Im, Pesaran ve Shin (2003) IPS ve Levin, Lin ve Chu (2002) LLC birinci nesil testler ile analiz edilmiştir. Modelin hangi yöntem kullanılarak tahmin edileceğinin seçimi için ise F testi, Breuch-Pagan LM (1980), Honda (1985) testleri ve Hausman (1978) testi uygulanmıştır. Modellerde hata terim varyansının tüm gözlemler için aynı olmama durumunu ifade eden değişen varyans, Breusch-Pagan-Godfrey Heteroscedasticity LM ile incelenirken otokorelasyon ise Baltagi ve Li (1991), Born ve Bretuing (2016) ve Bhargava, Franzini ve Narendranathan (1982)'ın Durbin-Watson testleri ile incelenmektedir. Model tahmini ise Beck ve Katz (1995) tarafından geliştirilen panel standart hataları düzelten, Period SUR (PCSE) yöntemi kullanılarak gerçekleştirilmiştir.

\section{4. Çoklu Doğrusal Bağlantının Araştırılması}

Panel regresyon modelinde açıklayıcı değişkenlerin tümü ya da bir kısmı arasında olan tam veya tama yakın doğrusal ilişki, çoklu doğrusal bağlantı olarak karşımıza çıkmaktadır. Açıklayıcı değişkenler arasında yüksek dereceli korelasyon ilişkisi parametrelerin hesaplanmasını imkansız hale getirebilmekte ve en küçük kareler metodunu kullanılmaz bir duruma getirebilmektedir. Dolayısıyla panel veri analizi kapsamında öncelikle bağımsız değişkenler arasında çoklu doğrusal bağlantı sorununun olup olmadığı, literatürde sıklıkla kullanılan spearman korelasyon analizi ve varyans şişirme testi ile araştırılmıştır. Çoklu doğrusal bağlantı sorununa yol açabilecek kritik değerlerin üzerinde değer alan değişkenler analizden çıkarılmıştır. Korelasyon ve Varyans Şişirme Faktör (VIF) analizlerine ilişkin sonuçlar aşağıda Tablo 4 ve 5'te gösterilmektedir. 
Tablo 4: Spearman Korelasyon Analiz Sonuçları

\begin{tabular}{|c|c|c|c|c|c|c|}
\hline \multicolumn{7}{|l|}{$\begin{array}{l}\text { Korelasyon } \\
\text { t-İstatisik }\end{array}$} \\
\hline \multirow[t]{3}{*}{ BUY } & 1.000000 & & & & & \\
\hline & ---- & & & & & \\
\hline & ---- & & & & & \\
\hline \multirow[t]{3}{*}{ FIKD } & 0.242937 & 1.000000 & & & & \\
\hline & 4.175663 & ---- & & & & \\
\hline & 0.0000 & ----- & & & & \\
\hline \multirow[t]{3}{*}{ LKDT } & 0.019870 & -0.483916 & 1.000000 & & & \\
\hline & 0.331361 & -9.219936 & ---- & & & \\
\hline & 0.7406 & 0.0000 & ----- & & & \\
\hline \multirow[t]{3}{*}{ NFM } & -0.082704 & 0.409096 & -0.527736 & 1.000000 & & \\
\hline & -1.383689 & 7.475127 & -10.35912 & ---- & & \\
\hline & 0.1676 & 0.0000 & 0.0000 & ----- & & \\
\hline \multirow[t]{3}{*}{ ROA } & 0.042955 & 0.045244 & -0.142811 & 0.227220 & 1.000000 & \\
\hline & 0.716865 & 0.755148 & -2.405799 & 3.890262 & ---- & \\
\hline & 0.4741 & 0.4508 & 0.0168 & 0.0001 & ---- & \\
\hline \multirow[t]{3}{*}{ ROE } & 0.327481 & 0.325738 & -0.263098 & 0.300484 & 0.731446 & 1.000000 \\
\hline & 5.778867 & 5.744431 & -4.546914 & 5.252815 & 17.88480 & ----- \\
\hline & 0.0000 & 0.0000 & 0.0000 & 0.0000 & 0.0000 & ----- \\
\hline
\end{tabular}

Tablo 4'te bağımsız değişkenler arasında tam ilişki olmaması gerekliliğine işaret eden çoklu doğrusal bağlantı varsayımını test etmek için bağımsız değişkenler arasındaki korelasyon katsayıları incelenmiştir. Değişkenler arasındaki korelasyon katsayısının 0.90'ın üzerinde olması sorun yaratmaktadır (Tabachnick ve Fidell, 2001). Çalışmada kullanılan değişkenler arasında en yüksek korelasyon katsayısı 0.73 olarak hesaplanmıştır. Çoklu doğrusal bağlantı sorununu belirleyebilmek amacıyla kullanılan bir diğer ölçüt ise Varyans Şişirme Faktör (VIF) değerleridir. VIF değerinin 10'dan küçük olması da değişkenler arasında çoklu doğrusal bağlantı sorununun olmadığına işaret etmektedir (Hair, vd. 1998).

Tablo 5: Varyans Şişirme Faktör (VIF) Değerleri

\begin{tabular}{lcc}
\hline Değişken & $\begin{array}{c}\text { Varyans } \\
\text { Katsayısı }\end{array}$ & $\begin{array}{c}\text { Merkezi } \\
\text { VIF Değeri }\end{array}$ \\
\hline BUY & $1.33 \mathrm{E}-05$ & 1.703724 \\
FIKD & 0.002705 & 2.155728 \\
LKDT & 0.000238 & 1.175309 \\
NFM & 0.021700 & 1.254801 \\
ROA & 0.728674 & 3.726359 \\
ROE & 0.006773 & 3.713985 \\
C & 0.006026 & NA \\
\hline
\end{tabular}

Tablo 5'te yer alan VIF değerleri incelendiğinde, çalışmada kullanılan bağımsız değişkenlerin VIF değerleri 1.17 ile 3.72 arasında değer aldıkları tespit edilmiştir. Dolayısıyla bağımsız değişkenler arasında çoklu doğrusal bağlantı sorununun olmadığı söylenebilir. Bu bulgular, korelasyon analizinden elde edilen sonuçları destekler niteliktedir. 


\subsection{Yatay Kesit Bağımlılığının Test Edilmesi}

Seriler arasında yatay kesit bağımlılığı söz konusu ise bu durum dikkate alınarak analiz yapılması bulguların doğruluğunu ve güvenilirliğini etkilemektedir (Breusch- Pagan, 1980; Pesaran, 2004). Yatay kesit bağımlıı̆̆ının göz önünde bulundurulmadığı analiz sonuçları, sapmalı ve tutarsız hale gelebilmektedir. Bu doğrultuda panel veri analizi öncesi serilerde yatay kesit bağımıılığının olup olmadığının test edilmesi gerekmektedir. Seriler arasında yatay kesit bağımlılı̆ının varlığı, Breusch-Pagan (1980) LM testi, Pesaran (2004) CD ve CDIm testleri veya Pesaran, Ullah ve Yagamata (2008) LMadj testi ile tespit edilebilmektedir. Breusch-Pagan (1980) LM testi, zaman boyutu yatay kesit boyutundan çok büyük olduğunda (T>N), Pesaran (2004) CDIm testi, zaman boyutunun yatay kesit boyutundan büyük olduğu $(T>N)$ ancak iki boyut arasındaki farkın fazla olmadığı durumlarda kullanılmaktadır. Pesaran (2004) CD testi, yatay kesit boyutunun zaman boyutundan büyük olduğu durumlarda $(\mathrm{N}>\mathrm{T})$ kullanılırken, Pesaran, Ullah ve Yagamata (2008) LMadj testi, LM testindeki sapmaları ve Pesaran CD testindeki korelasyon toplamının 0 olma ihtimalini ortadan kaldırmakta ve $\mathrm{T}$ boyutunun $\mathrm{N}$ boyutundan büyük olduğu durumlarda kullanılmaktadır.

Paneli oluşturan birimler arasında yatay kesit bağımlılığının varlı̆̆ı, Gauss kodları yardımıyla panel bazında ve değişken bazında ayrı ayrı incelenmiştir. Tablo 6 'da model 1 için panel geneli yapılan yatay kesit bağımlılığı analiz sonuçları verilmektedir.

Tablo 6: Model 1 İçin Panel Bazında Yatay Kesit Bağımlıı̆ı Test Sonuçları

\begin{tabular}{ccc}
\hline CD Testleri & istatistik & Olasilık Değeri \\
\hline$C D_{l m}(\mathrm{BP}, 1980)$ & 307.132 & 0.000 \\
$C D_{l m}($ Pesaran, 2004) & 6.009 & 0.000 \\
$C D_{(\text {Pesaran, 2004) }}$ & 10.253 & 0.000 \\
$L M_{a d j}(\mathrm{PUY}, 2008)$ & 5.164 & 0.000 \\
\hline
\end{tabular}

$\mathrm{H}_{0}$ : Kesitler arasında bağımlıık yoktur

$\mathrm{H}_{1}$ : Kesitler arasında bağımlılık vardır.

Tablo 6'da yer alan panel bazında yapılan yatay kesit bağımlılı̆̆ (YKB) testlerine ilişkin sonuçlar incelendiğinde, YKB için gerçekleştirilen bütün testlerde olasılık değerinin 0.05 'ten küçük çıktığı tespit edilmiştir. Çalışmada N boyutu T boyutundan büyük olduğu için Pesaran CD (2004) test sonuçları dikkate alınmıştır. Dolayısıyla sıfır hipotez olan "kesitler arasında bağımlılık yoktur" reddedilmektedir. Paneli oluşturan kesitler arasında yatay kesit bağımlılığı söz konusudur. Diğer bir deyişle bankalardan birine gelen bir birim şok diğer bankaları da etkilemektedir. Bu sebeple her banka finansal kırılganlıklarını azaltabilmek için diğer bankaların finansal kırılganIıklarını etkileyen şokları da dikkate almak durumundadır.

Çalışmada kullanılan değişkenlerin durağanlık sınamaları için hangi birim kök testlerinin uygulanacağı, değişken bazında gerçekleştirilen yatay kesit bağımlılığı testi ile belirlenmiştir. Analiz sonuçları Tablo 7'de sunulmaktadır. 
Tablo 7: Değişken Bazında Yatay Kesit Bağımlılığı Test Sonuçları

\begin{tabular}{|l|c|c|c|c|c|c|c|c|}
\hline \multirow{2}{*}{ Değişken } & \multicolumn{2}{|c|}{ LM } & \multicolumn{2}{c|}{$\begin{array}{c}\text { CDIm } \\
\text { (Pesaran 2004) }\end{array}$} & \multicolumn{2}{c|}{$\begin{array}{c}\text { CD } \\
\text { (Pesaran 2004) }\end{array}$} & \multicolumn{2}{c|}{$\begin{array}{c}\text { LMadj } \\
\text { (PUY, 2008) }\end{array}$} \\
\cline { 2 - 9 } & İstat. & Olasılık D. & İstat. & Olasılık D. & İstat. & Olasılık D. & İstat. & Olasılık D. \\
\hline FINK & 641.563 & 0.000 & 23.165 & 0.000 & $\mathbf{9 . 3 6 9}$ & $\mathbf{0 . 0 0 0}$ & 2.564 & 0.005 \\
\hline FIKD & 347.478 & 0.000 & 8.078 & 0.000 & $\mathbf{- 1 . 0 1 0}$ & $\mathbf{0 . 1 5 6}$ & 3.602 & 0.000 \\
\hline SYO & 351.384 & 0.000 & 8.279 & 0.000 & $\mathbf{0 . 3 5 4}$ & $\mathbf{0 . 3 6 2}$ & 7.211 & 0.000 \\
\hline BUY & 396.009 & 0.000 & 10.568 & 0.000 & $\mathbf{0 . 4 5 7}$ & $\mathbf{0 . 3 2 4}$ & 8.733 & 0.000 \\
\hline LKDT & 313.308 & 0.000 & 6.326 & 0.000 & $\mathbf{3 . 4 9 5}$ & $\mathbf{0 . 0 0 0}$ & - & - \\
\hline NFM & 368.672 & 0.000 & 9.166 & 0.000 & $\mathbf{1 . 5 3 7}$ & $\mathbf{0 . 0 6 2}$ & 0.238 & 0.406 \\
\hline ROA & 433.784 & 0.000 & 12.506 & 0.000 & $\mathbf{0 . 1 0 6}$ & $\mathbf{0 . 4 5 8}$ & 0.658 & 0.255 \\
\hline ROE & 338.463 & 0.000 & 7.616 & 0.000 & $\mathbf{1 . 3 6 8}$ & $\mathbf{0 . 0 8 6}$ & 2.723 & 0.003 \\
\hline
\end{tabular}

Gecikme sayısı $\left(\mathrm{p}_{\mathrm{i}}\right)$, çalışmanın zaman boyutu dikkate alınarak 2 olarak belirlenmiştir.

$\mathrm{H}_{0}$ : Yatay kesit bağımlılığı yoktur.

$\mathrm{H}_{1}$ : Yatay kesit bağımlılı̆̆ vardır.

Çalışmada, yatay kesit boyutu zaman boyutundan büyük olduğu için Pesaran CD (2004) test sonuçları yatay kesit bağımlıı̆̆ı açısından dikkate alınmıştır. Analiz sonucunda FINK ve LKDT değişkenlerinin olasılık değerleri kritik değer olarak kabul edilen 0.05 'ten küçük olduğu için sıfır hipotezi reddedilmektedir. Yani bu iki değişkende yatay kesit bağımlılığı sorunu söz konusudur. Diğer taraftan FIKD, SYO, BUY, NFM, ROA ve ROE değişkenlerinin olasılık değerleri kritik değerin üzerinde olduğu için sıfır hipotezi reddedilememektedir. Yani bu değişkenlerde yatay kesit bağımlılığı yoktur. Dolayısıyla FINK ve LKDT değişkenleri için durağanlık sınaması gerçekleştirilirken yatay kesit bağımlıığını dikkate alan ikinci nesil birim kök testleri kullanılmıştır.

Panel veri analizinde seriler arasında yatay kesit bağımlılığı söz konusu değil ise durağanlık için uygulanması gereken birim kök testlerinin belirlenmesinde homojenlik testlerinin yapılması gerekmektedir. Homojenlik, panel bazında ve her bir değişken için ayrı ayrı yapılabilmektedir. Panel bazında yapılan homojenlik sınaması, açıklayıcı değişkenler haricinde kalan sabit terimlerin yani $\alpha^{\prime}$ nın ve her bir değişkenin eğim katsayısının yani $\beta^{\prime}$ sının (bağımlı değişkene etkisi) homojen ya da heterojen olup olmadığını tespit etmektedir.

\subsection{Parametlerde Homojenliğin/Heterojenliğin Test Edilmesi}

Yatay kesit bağımlılığı analizi sonrasında, panel veri analizine geçmeden önce sınanması gereken bir diğer varsayım ise homojenlik varsayımıdır. Pesaran ve Yamagata (2008) delta testleri ile sabit terimin ve eğim katsayılarının her bir banka için homojen mi yoksa heterojen mi olduğu tespit edilebilmektedir. Tablo 8'de model 1 için gerçekleştirilen homojenite analiz sonuçları gösterilmektedir.

Tablo 8: Panel Bazında Pesaran and Yamagata (2008) Homojenite Test Sonuçları

\begin{tabular}{|l|c|c|c|c|}
\hline Değişken & Delta_tilde & Olasılık Değeri & Düzeltilmiş_Delta_tilde & Olasılık Değeri \\
\hline $\boldsymbol{\alpha}$ (Sabit Terim) & 3.601 & 0.000 & 5.271 & 0.000 \\
\hline $\boldsymbol{\beta}$ FIKD & 7.546 & 0.000 & 8.514 & 0.000 \\
\hline $\boldsymbol{\beta}$ BUY & 2.022 & 0.022 & 2.281 & 0.011 \\
\hline $\boldsymbol{\beta}$ LKDT & 2.380 & 0.009 & 2.816 & 0.002 \\
\hline $\boldsymbol{\beta}$ NFM & 2.991 & 0.001 & 3.731 & 0.000 \\
\hline $\boldsymbol{\beta}$ ROA & 1.977 & 0.024 & 2.615 & 0.004 \\
\hline $\boldsymbol{\beta}$ ROE & 1.919 & 0.027 & 2.714 & 0.003 \\
\hline
\end{tabular}

$\mathrm{H}_{0}$ : Homojenlik vardır.

$\mathrm{H}_{1}$ : Homojenlik yoktur. 
Sabit terim ve her bir değişkenin eğim katsayılarının homojenliğine ilişkin yapılan delta testi sonucuna göre, tahmin edilecek modele ait delta ve düzeltilmiş delta olasılık değerlerinin 0.05 anlamlılık düzeyinden küçük olduğu için sabit terimin ve eğim katsayılarının homojen olduğunu savunan sıfır hipotezi reddedilmektedir. Yani sabit terimin ve her bir değişkenin eğim katsayılarının heterojen olduğu belirlenmiştir.

Panel bazında homojenlik sınaması sonrasında yatay kesit bağımlılığının olmadığı değişkenlerde hangi birim kök testinin kullanılacağı ise değişken bazında gerçekleştirilen homojenite analiz sonuçlarına göre tespit edilmiştir. Homojenite test sonuçları, Tablo 9'da yer almaktadır.

Tablo 9: Değişken Bazında Pesaran and Yamagata (2008) Homojenite Test Sonuçları

\begin{tabular}{|l|c|c|c|c|}
\hline Değişken & Delta_tilde & Olasılık Değeri & Düzeltilmiş_Delta_tilde & Olasılık Değeri \\
\hline FINK & 1.105 & 0.135 & 1.246 & 0.106 \\
\hline FIKD & 2.559 & 0.005 & 2.887 & 0.002 \\
\hline SYO & 1.157 & 0.124 & 1.306 & 0.096 \\
\hline BUY & 2.249 & 0.012 & 2.537 & 0.006 \\
\hline LKDT & -0.766 & 0.778 & -0.864 & 0.806 \\
\hline NFM & 2.827 & 0.002 & 3.189 & 0.001 \\
\hline ROA & 0.525 & 0.300 & 0.593 & 0.277 \\
\hline ROE & 2.998 & 0.001 & 3.383 & 0.000 \\
\hline
\end{tabular}

Ho: Homojenlik vardır.

$\mathrm{H}_{1}$ : Homojenlik yoktur.

Homojenite test sonuçları incelendiğinde, FIKD, BUY, NFM ve ROE değişkenlerinin olasılık değerlerinin kritik değer olan 0.05 'ten küçük olduğu belirlenmiştir. Dolayısıyla sıfır hipotezi reddedilmektedir. Diğer bir deyişle bu değişkenlerin, heterojen oldukları tespit edilmiştir. FINK, LKDT, SYO ve ROA değişkenlerinin olasılık değerleri ise kritik değerin üzerindedir ve sıfır hipotezi reddedilememektedir. Diğer bir ifadeyle bu değişkenler homojendir. FIKD, BUY, NFM ve ROE değişkenleri için durağanlık sınamaları, yatay kesit bağımlılığını dikkate almayan ve heterojen yapıya sahip olan birinci nesil birim kök testleri aracılığıyla gerçekleştirilmiş̧tir. SYO ve ROA değişkenleri için durağanlık ise yatay kesit bağımlılığını dikkate almayan ve homojenik yapıya sahip olan testler kullanılarak sınanmıştır.

\subsection{Panel Birim Kök Testleri}

Panel veri analizini gerçekleştirebilmek ve doğru sonuçlar elde edebilmek için değişkenlere ilişkin zaman serilerinin durağanlığının sağlanması gerekmektedir (Gujarati, 2003). Diğer bir deyişle, bağımlı ve bağımsız değişkenler arasında anlamlı sonuçların sağlanabilmesi için serilerin durağan olmaları gerekmektedir. Panel veri analizinde birim kök sınaması öncesinde yatay kesitlerin birbirinden bağımsız olup olmadıklarının belirlenmesi gerekmektedir. Bu noktada panel birim kök testleri, yatay kesit bağımlılı̆ını dikkate almaları doğrultusunda birinci ve ikinci nesil testler olmak üzere ikiye ayrılmaktadır. Birinci nesil birim kök testleri, yatay kesit birimlerinin birbirinden bağımsız olduğu ve paneli oluşturan kesitlerden birinde meydana gelen şokun tüm kesitleri aynı düzeyde etkilediği varsayımına dayanmaktadır. Ayrıca bu testler, homojen ve heterojen modeller olmak üzere de iki gruba ayrılmaktadır. Levin, Lin ve Chu (2002) ve Breitung (2005) testleri homojenlik varsayımına dayanırken; Im, Pesaran ve Shin (2003), Maddala ve Wu (1999) ve Choi (2001) testleri ise heterojenlik varsayımına dayanmaktadır. Hadri (2000) testi ise hem homojenlik hem de heterojenlik varsayımına dayanmaktadır. İkinci nesil birim kök testleri ise yatay kesit birimlerinin birbirinden bağımsız olmadığı ve paneli oluşturan kesitlerden birinde 
meydana gelen şokun tüm kesitleri farklı düzeyde etkilediği varsayımına dayanmaktadır. Bu bağlamda yatay kesitler arasındaki yatay kesit bağımlılı̆ını dikkate alan ikinci nesil birim kök testleri geliştirilmiştir. Başlıca bu testler, Breuer vd. (2002) SURADF, Smith vd. (2004) Bootstrap, Bai ve Ng (2004) PANIC, Pesaran (2007) CADF ve CIPS, Hadri ve Kurozumi (2012) HK testleridir.

Çalışmada kullanılan değişkenlerin durağanlıkları, yatay kesit bağımlılığı ve homojenite durumları dikkate alınarak sınanmıştır. Yatay kesit bağımlılığı testi sonucunda bankalar arasında yatay kesit bağımlılığının tespit edildiği FIKD ve LKDT değişkenlerinin durağanlık sınamaları için Bai ve Ng (2004) PANIC testi kullanılmıştır. PANIC test sonuçları Tablo 10'da gösterilmektedir.

Tablo 10: PANIC Panel Birim Kök Testi Sonuçları

\begin{tabular}{|c|c|c|c|c|}
\hline \multirow{2}{*}{ Seviye } & \multicolumn{2}{|c|}{ Sabit } & \multicolumn{2}{|c|}{ Sabit ve Trend } \\
\hline & İstatistik & p-değeri & İstatistik & p-değeri \\
\hline \multicolumn{5}{|l|}{ FiNK } \\
\hline$Z_{c}$ & -0.8584 & 0.8047 & -1.6275 & 0.9482 \\
\hline$P_{\hat{e}}$ & 32.3224 & 0.8008 & 25.4428 & 0.9644 \\
\hline \multicolumn{5}{|l|}{$\underline{L K D T}$} \\
\hline$Z$ & -1.7352 & 0.9586 & $1.4606^{*}$ & 0.0721 \\
\hline$P_{\hat{e}}$ & 24.4798 & 0.9746 & $53.0638^{*}$ & 0.0809 \\
\hline \multicolumn{5}{|l|}{ Birinci Fark } \\
\hline \multicolumn{5}{|l|}{ FiNK } \\
\hline$Z_{c}$ & $4.4222^{* * *}$ & 0.0000 & $2.3390^{* * *}$ & 0.0097 \\
\hline$P_{\hat{e}}$ & $79.5537^{* * *}$ & 0.0002 & $60.9205^{* *}$ & 0.0181 \\
\hline \multicolumn{5}{|l|}{$\underline{L K D T}$} \\
\hline$Z_{c}$ & $6.2791^{* * *}$ & 0.0000 & $4.7037^{* * *}$ & 0.0000 \\
\hline$P_{\hat{e}}$ & $96.1619^{* * *}$ & 0.0000 & $82.0708^{* * *}$ & 0.0001 \\
\hline
\end{tabular}

Not 1: Maksimum ortak faktör sayısı 2 olarak alınmıştır. Maksimum gecikme uzunluğu 2 olarak belirlenmiştir.

Not 2: $* * *, * *$ ve * sırasıyla $\% 1, \% 5$ ve $\% 10$ anlamlılık düzeyini göstermektedir.

$* * *, * *$ ve * sıfır hipotezinin sırasıyla $\% 1, \% 5$ ve $\% 10$ anlamlılık düzeyinde reddedildiğini göstermektedir.

Not 3: Tabloda; Finansal Kırılganlık (FINK) ve Likidite Oranı (LKDT) ile gösterilmektedir.

Tablo 10'daki sonuçlar incelendiğinde, FINK ve LKDT değiş̧kenlerine ilişkin serilerin sabit ve sabit +trend'de düzeyde durağan olmadıkları ve birinci farkları alındığında durağan hale geldikleri yani I(1) oldukları tespit edilmiştir.

Yatay kesit birimlerinin birbirinden bağımsız olduğu diğer bir deyişle yatay kesit bağımlılığının olmadığı ancak yapılan homojenite testi sonucunda homojen yapıda olduğu belirlenen SYO ve ROA değişkenlerinin durağanlıkları için birinci nesil birim kök testlerinden olan ve homojenik yapıya sahip olan Levin, Lin ve Chu (2002) testi kullanılmıştır. LLC test sonuçları Tablo 11'de gösterilmektedir. 
Tablo 11: LLC Panel Birim Kök Test Sonuçları

\begin{tabular}{|c|c|c|c|c|}
\hline & \multicolumn{4}{|c|}{ Sabit } \\
\hline & \multicolumn{2}{|c|}{ SYO } & \multicolumn{2}{|c|}{ ROA } \\
\hline & İsta. & p-değer & İsta. & p-değer \\
\hline \multirow[t]{4}{*}{ LLC } & $-4.2748^{* * *}$ & 0.0000 & $-7.7651^{* * *}$ & 0.0000 \\
\hline & \multicolumn{4}{|c|}{ Sabit + Trend } \\
\hline & \multicolumn{2}{|c|}{ SYO } & \multicolumn{2}{|c|}{ ROA } \\
\hline & İsta. & p-değer & İsta. & p-değer \\
\hline LLC & $-8.3890^{* * *}$ & 0.0000 & $-13.0942^{* * *}$ & 0.0000 \\
\hline
\end{tabular}

Not 1: LLC testinde uzun dönem tutarlı hata varyansı hesaplanırken "Kernel” tahmincisi olarak Barlett yöntemi kullanılmış ve bant genişliği “bandwith” Newey-West yöntemine göre seçilmiştir. LLC tesinde, maksimum gecikme uzunluğu 2 olarak alınmış ve optimal gecikme uzunluğu Schwarz bilgi kriterine göre belirlenmiştir.

Not 2: $* * *, * *$ ve * sırasıyla $\% 1, \% 5$ ve $\% 10$ anlamlılık düzeyini göstermektedir.

$* * *, * *$ ve * sıfır hipotezinin sırasıyla \%1, \%5 ve \%10 anlamlılık düzeyinde reddedildiğini göstermektedir.

Tablo 11'deki sonuçlar incelendiğinde, SYO ve ROA değişkenlerine ilişkin serilerin sabit ve sabit +trend'de düzeyde durağan oldukları yani I(0) oldukları tespit edilmiştir.

Yatay kesit bağımlılı̆ının olmadığı ancak yapılan homojenite testi neticesinde heterojen yapıda olduğu belirlenen FIKD, BUY, NFM ve ROE değişkenlerinin durağanlıkları için birinci nesil birim kök testlerinden olan ve heterojenik yapıya sahip olan Im, Pesaran ve Shin (2003) IPS testi kullanılmıştır. IPS test sonuçları Tablo 12'de gösterilmektedir.

Tablo 12: IPS Panel Birim Kök Test Sonuçları

\begin{tabular}{|c|c|c|c|c|c|c|c|c|}
\hline \multirow{3}{*}{ Seviye } & \multicolumn{8}{|c|}{ Sabit } \\
\hline & \multicolumn{2}{|c|}{ FIKD } & \multicolumn{2}{|c|}{ BUY } & \multicolumn{2}{|c|}{ NFM } & \multicolumn{2}{|c|}{ ROE } \\
\hline & İsta. & p-değer & İsta. & p-değer & İsta. & p-değer & İsta. & p-değer \\
\hline IPS & -2.586 & 0.004 & 0.267 & 0.605 & -11.976 & 0.000 & -6.318 & 0.000 \\
\hline \multicolumn{9}{|l|}{ Birinci Fark } \\
\hline \multirow[t]{2}{*}{ IPS } & & & -9.037 & 0.000 & & & & \\
\hline & \multicolumn{8}{|c|}{ Sabit + Trend } \\
\hline \multirow[t]{2}{*}{ Seviye } & \multicolumn{2}{|c|}{ FIKD } & \multicolumn{2}{|c|}{ BUY } & \multicolumn{2}{|c|}{ NFM } & \multicolumn{2}{|c|}{ ROE } \\
\hline & İsta. & p-değer & İsta. & p-değer & İsta. & p-değer & İsta. & p-değer \\
\hline IPS & -3.782 & 0.000 & -2.374 & 0.008 & -7.275 & 0.000 & -10.765 & 0.000 \\
\hline Birinci Fark & & & & & & & & \\
\hline IPS & & & & & & & & \\
\hline
\end{tabular}

IPS testinde uzun dönem tutarlı hata varyansı hesaplanırken "Kernel” tahmincisi olarak Barlett yöntemi kullanılmış ve bant genişliği "bandwith" Newey-West yöntemine göre seçilmiştir. IPS tesinde, maksimum gecikme uzunluğu 2 olarak alınmış ve optimal gecikme uzunluğu Schwarz bilgi kriterine göre belirlenmiştir.

$* * *, * *$ ve * sırasıyla \%1, \%5 ve \%10 anlamlılık düzeyini göstermektedir.

$* * *, * *$ ve * sıfır hipotezinin sırasıyla \%1, \%5 ve \%10 anlamlılık düzeyinde reddedildiğini göstermektedir.

Tablo 12' deki sonuçlar incelendiğinde, FIKD, NFM ve ROE değişkenlerine ilişkin serilerin sabit ve sabit +trend'de düzeyde durağan oldukları yani I(0) oldukları tespit edilmiştir. BUY değişkenine ilişkin serilerin sabit terimde düzeyde durağan olmadığı ve birinci farkı alındığında durağan hale geldiği yani I(1) olduğu tespit edilmiştir.

\subsection{Panel Veri Modellerinin Tahmini}

Finansal kırılganlığa etki eden mikro faktörleri tespit edebilmek için sabit etkiler modeli, rassal etkiler modeli ve havuzlanmış modelden hangisinin tahminleme için kullanılacağına $F$ testi, 
Breuch-Pagan LM (1980) ve Honda (1985) testleri ile karar verilmiştir. Bu testlere ilişkin analiz sonuçları Tablo 13'te gösterilmektedir.

Tablo 13: Tahmin Modeli Belirleme Analiz Sonuçları

\begin{tabular}{lcccc}
\hline \multicolumn{1}{c}{ Test } & İsta. & p-değeri & Hipotez & Karar \\
\hline F-grup_fixed & 1.157 & 0.296 & $\mathrm{H}_{0}$ :Kesit etkisi varken zaman etkisi yoktur. & REDDEDiLEMEZ \\
$\begin{array}{l}\text { F-zaman_fixed } \\
\text { F-iki yönlü_fixed }\end{array}$ & 1.486 & 0.054 & $\mathrm{H}_{0}$ :Kesit ve zaman etkisi yoktur & RED \\
\hline LM-grup_random & 0.265 & 0.606 & $\mathrm{H}_{0}$ :Kesit etkisi varken zaman etkisi yoktur. & REDDEDiLEMEZ \\
LM-zaman_random & 4.120 & 0.042 & $\mathrm{H}_{0}$ :Zaman etkisi varken kesit etkisi yoktur. & RED \\
LM-iki yönlü_random & 4.385 & 0.111 & $\mathrm{H}_{0}$ :Kesit ve zaman etkisi yoktur & REDDEDiLEMEZ \\
\hline Honda-grup_random & -0.514 & 0.696 & $\mathrm{H}_{0}$ :Kesit etkisi varken zaman etkisi yoktur. & REDDEDiLEMEZ \\
Honda-zaman_random & 2.029 & 0.021 & $\mathrm{H}_{0}$ :Zaman etkisi varken kesit etkisi yoktur. & RED \\
Honda-iki yönlü_random & 1.071 & 0.142 & $\mathrm{H}_{0}$ :Kesit ve zaman etkisi yoktur & REDDEDiLEMEZ \\
\hline Hausman & 5.754 & 0.451 & & \\
\hline
\end{tabular}

Modelin havuzlanmış modelle mi yoksa sabit etkiler modeli ile tahmin edilip edilmeyeceğinin tespit edilebilmesi için $\mathrm{F}$ testi sonuçları dikkate alınmaktadır. Tablo 13'teki F testi sonuçları incelendiğinde, olasılık değerinin kritik değerin altında olduğu belirlenmiş ve sıfır hipotezi reddedilmiştir. Dolayısıyla modelin havuzlanmış model yerine sabit etkiler modeli ile tahmin edilmesi daha etkindir. Ayrıca grup ve zaman etkilerinin varlığına ilişkin test istatistikleri değerlendirildiğinde, tahmin edilecek modelde zaman etkisinin olduğu buna karşın kesit etkisinin olmadığı tespit edilmiştir.

Tahmin modeli için havuzlanmış model ile rassal etkiler modeli arasından hangisinin daha etkin olduğunu belirleyebilmek amacıyla Breuch-Pagan LM (1980) ve Honda (1985) testleri uygulanmıştır. Havuzlanmış ya da rassal etkiler modelleri arasından hangisinin tercih edilmesi gerektiği ve oluşturulan veri seti doğrultusunda zaman ya da kesit etkilerinin varlığı en doğru ve gelişmiş şekilde Honda (1985) yöntemi ile belirlenmektedir. Analiz sonuçlarına göre, her iki test için de olasılık değeri kritik değerin altında olduğu için rassal etkiler modelinin havuzlanmış modele göre etkinliği ortaya koyulmuştur. Grup ve zaman etkilerinin varlığına ilişkin test istatistikleri değerlendirildiğinde, $\mathrm{F}$ testinde olduğu gibi tahmin edilecek modelde zaman etkisinin olduğu buna karşın kesit etkisinin olmadığı belirlenmiştir.

Hausman testi, model seçiminde kullanılan bir test değildir. Bu test, sabit etkiler modeli tutarlıyken rassal etkiler modelinin tutarlı olup olmadığına ve veri seti rassal olarak oluşturulurken sabit etkiler modelinin tutarlı olup olmadığına karar vermek için kullanılmaktadır (Erlat, 2015: 24). Hausman testi, sabit etkiler modeli tahmincisi within estimator ile rassal etkiler modeli tahmincileri EGLS ve FGLS arasında seçim yapmaya yaramaktadır. Hausman test istatistik değeri 0.05 kritik değerin altında ise sıfır hipotezi reddedilmektedir. Bu sonuç, EGLS ve FGLS tahmincilerinin tutarsız olduğu ve rassal etkiler modeli tahmin edilirken within estimator tahmincisinin kullanılması gerektiği anlamına gelmektedir. Diğer taraftan Hausman test istatistik değeri kritik değerden yüksek ise rassal etkiler modeli EGLS ve FGLS ile tahmin edilmektedir. Hausman test sonucu incelendiğinde, olasılık değerinin kritik değerden yüksek çıktığı görülmektedir. Dolayısıyla, rassal etkiler modeli tercih edilirse Panel EGLS ile tahmin etmek gerekmektedir. 
Çalışmada incelenen dönem ve bankalar dikkate alındığında, veri setinin belirli bir gruba ve belirli bir döneme ait olduğu görülmektedir. Model tahminlemesinin hangi model ile yapılması gerektiğine ilişkin analiz sonuçları doğrultusunda çalışmada, sabit etkiler modeli esas alınarak en küçük kareler yöntemi (within estimator) kullanılarak tahminleme yapılmıştır.

\subsection{Değişen Varyans ve Otokorelasyonun Test Edilmesi}

Değişen varyans ve otokorelasyon varsayımları panel veri analizinde hata terimi ile ilgili temel varsayımları oluşturmaktadır. Değişen varyans, sabit varyans varsayımının geçerli olmamasını ifade etmektedir. Diğer bir deyişle, hata terimlerinin varyanslarının tüm kesitler için farklı olması ve kovaryanslarının sıfıra eşit olmaması anlamına gelmektedir. Hata teriminin koşullu varyansının değişkenlik göstermesi özellikle yatay kesit verileriyle analizinde sıklıkla rastlanılan bir sorundur.

Otokorelasyon varsayımı ise hata teriminin birbirini izleyen değerleri arasındaki anlamlı ilişkiyi ifade etmektedir. Birim değerlerinin birbirini etkilemesi diğer bir ifadeyle birim değerlerinin birbirinden bağımsız olmaması panel veri analizinde sistematik bir ilişkiye sebep olmaktadır. Bu durum da panel veri analizinde sapmalara ve tutarsızıklara yol açabilmektedir. Otokorelasyon sorunu, genellikle zaman ve kesit boyutunun incelendiği panel veri analizlerinde sıkça karşılaşılan bir problemdir.

Çalışmada, değişen varyans varsayımı, Breusch-Pagan-Godfrey Heteroscedasticity LM testi ile incelenirken; otokorelasyon varsayımı ise Baltagi ve Li (1991), Born ve Bretuing (2016) ve Bhargava, Franzini ve Narendranathan (1982)'ın Durbin-Watson testleri ile incelenmiştir. Sabit etkiler modeli esas alınarak hesaplanmış değişen varyans ve otokorelasyon test istatistikleri Tablo 14'te gösterilmektedir.

Tablo 14: Sabit Etkiler Modeli Iç̧in Değişen Varyans ve Otokorelasyon Test Sonuçları

\begin{tabular}{|c|c|c|}
\hline \multicolumn{3}{|c|}{ Değişen Varyans } \\
\hline Breusch-Pagan-Godfrey LMh_fixed & 845.6687 & 0.000000 \\
\hline $\begin{array}{l}\mathrm{H}_{0} \text { : Değişen Varyans yoktur } \\
\mathrm{H}_{1} \text { : Değişen Varyans vardır }\end{array}$ & & \\
\hline \multicolumn{3}{|c|}{ Otokorelasyon } \\
\hline Baltagi ve Li (1991) LMp-stat & 4.617512 & 0.031647 \\
\hline \multicolumn{3}{|l|}{$\begin{array}{l}\mathrm{H}_{0} \text { : Otokorelasyon yoktur } \\
\mathrm{H}_{1} \text { : Otokorelasyon vardır }\end{array}$} \\
\hline Born ve Bretuing (2016) LMp*-stat & 12.06995 & 0.000512 \\
\hline \multicolumn{3}{|l|}{$\mathrm{H}_{0}:$ Otokorelasyon yoktur } \\
\hline Durbin-Watson & & \\
\hline
\end{tabular}

Sabit etkiler modeli esas alınarak hesaplanmış değişen varyans ve otokorelasyon değerleri incelendiğinde, Breusch-Pagan-Godfrey LM olasılık değerinin, 0.05 kritik değerinden küçük olduğu tespit edilmiş ve sıfır hipotezi reddedilmiştir. Yani hata terimlerinin varyansları tüm kesitler için sabit değildir ve kovaryansları sıfırdan farklıdır. Diğer bir deyişle panelde değişen varyans sorunu söz konusudur. Otokorelasyon testlerine ilişkin sonuçlar değerlendirildiğinde, Baltagi ve Li (1991) LM ve Born ve Bretuing LM (2016) test olasılık değerleri, kritik değerin altındadır ve sıfır hipotezi reddedilmektedir. Diğer bir deyişle, hata terimlerinin birbirini izleyen değerleri birbirinden bağımsız değildir ve otokorelasyon sorunu mevcuttur. 280 gözlem sayısı için DurbinWatson $d$ testi tablosunda $d$ istatistiğinin $d L$ (alt) sınır değeri 1.9303 ve dU (üst) sınır değeri 
1.9390 olarak tespit edilmiştir (Bhargava vd., 1982: 537). Durbin-Watson test istatistik değerinin 1.6241 olduğu görülmektedir $(0<\mathrm{d}<\mathrm{dL})$. Bu değerlere göre tahmin edilen modele ilişkin Durbin-Watson değerleri otokorelasyonun olduğu bölgeye tekabül ettiği için otokorelasyon olduğuna karar verilmiştir.

\subsection{Tahmin Sonuçları}

Çalışmanın bu kısmında, bağımlı ve bağımsız değişkenler arasında istatistiksel olarak anlamlı bir ilişkinin olup olmadığı ve varsa bu ilişkinin yönü tespit edilmeye çalışımıştır. Çalışmada tahmin edilecek olan modelde hata terimlerinin varyanslarının sabit olmadığı ve hata teriminlerinin birbirini izleyen değerlerinin birbirinden bağımsız olmadığı belirlenmiştir. Diğer bir deyişle, modelde değişen varyans ve otokorelasyon sorunlarının varlığı tespit edilmiştir. Dolayısıyla çalışmada, bu sorunları dikkate alan ve çözen Beck ve Katz (1995) tarafından geliştirilen Period SUR (PCSE) yöntemi ile panel standart hataların düzeltilmesi yoluyla tahminleme gerçekleştirilmiştir. Tahmin sonuçları, Tablo 15 'te sunulmaktadır.

Tablo 15: Model Tahmin Sonuçları

\begin{tabular}{|c|c|c|c|c|}
\hline Bağımlı Değişken & \multicolumn{3}{|c|}{ Yöntem } & Örneklem \\
\hline FINKIR & \multicolumn{3}{|c|}{$\begin{array}{l}\text { Enküçük Kareler Yöntemi } \\
\text { Period SUR (PCSE) standard errors \& covariance (d.f. corrected) }\end{array}$} & $2002-2015$ \\
\hline Açıklayıcı Değişken & Katsayı & Standart Hata & t-İstatistiği & Olasılık \\
\hline BUY & -0.108039 & 0.022912 & $-4.715294^{* * *}$ & 0.0000 \\
\hline FINKAL & -0.035648 & 0.043752 & -0.814781 & 0.4160 \\
\hline LKDT & 0.083393 & 0.005165 & $16.14522^{* * *}$ & 0.0000 \\
\hline NFM & -0.439880 & 0.291677 & -1.508106 & 0.1328 \\
\hline ROA & -1.366620 & 0.899076 & -1.520028 & 0.1298 \\
\hline ROE & 0.121644 & 0.103290 & 1.177695 & 0.2401 \\
\hline \multirow[t]{9}{*}{ C } & 0.082057 & 0.033258 & $2.467256^{* *}$ & 0.0143 \\
\hline & \multicolumn{4}{|c|}{ Period Fixed (Dummy Variables) } \\
\hline & R-squared & 0.356212 & Mean dependent var & -0.007048 \\
\hline & Adjusted R-squared & 0.308128 & S.D. dependent var & 0.095028 \\
\hline & S.E. of regression & 0.079043 & Akaike info criterion & -2.167370 \\
\hline & Sum squared resid & 1.505734 & Schwarz criterion & -1.907167 \\
\hline & Log likelihood & 300.7582 & Hannan-Quinn criter. & -2.062765 \\
\hline & F-statistic & 7.408155 & Durbin-Watson stat & 1.599975 \\
\hline & Prob(F-statistic) & 0.000000 & & \\
\hline
\end{tabular}

Tabloda; Finansal Kırılganlık (FINK), Sermaye Yeterlilik Oranı (SYO), Finansal Kaldıraç Oranı (FIKD), Banka Büyüklüğü (BUY), Net Faiz Marjı (NFM), Likidite Oranı (LKDT), Aktif Karlıık Oranı (ROA) ve Özsermaye Karlıı̆̆ı (ROE) ile gösterilmektedir.

***,** ve * sırasıyla \%1, \%5 ve \%10 anlamlılık düzeyini göstermektedir.

Tablo 15'te finansal kırılganlığa etki eden mikro faktörlerin tespit edilebilmesi için oluşturulan model doğrultusunda gerçekleştirilen tahmin sonuçları yer almaktadır. Analiz sonuçları incelendiğinde, modelin bir bütün olarak anlamlılığını ifade eden $f$ istatistik olasılık değerinin \%99 güven düzeyinde anlamlı olduğu ve açıklayıcı değişkenlerin bağımlı değişkendeki değişimin $\% 35$ 'ini $\left(R^{2}\right)$ açıkladığı belirlenmiştir. Modelde banka büyüklüğü ve likidite oranı ile finansal kırılganlığı temsil eden takipteki kredi oranı arasında istatistiksel olarak anlamlı sonuçlar elde edilmiştir. Banka büyüklüğündeki \%1'lik bir değişim takipteki kredi oranında yaklaşık olarak $\% 10.8^{\prime}$ lik azalmaya yol açmaktadır. Bankaların sahip olduğu varlık miktarının artması, takipteki 
kredilerin geri dönmeme olasılığından dolayı ortaya çıkabilecek maliyeti düşürebilmektedir. Ayrıca varlıkların artması daha fazla kredi verilebilmesine imkân tanımakta ve bu durum da elde edilecek kazancın yükselmesine yol açabilmektedir. Kazancın artması ise takibe düşen ve geri ödeme olasılığı düşük olan verimsiz yatırımların maliyetlerini karşılayabilme açısından bankalara fırsat sunabilmektedir. Likidite oranındaki bir birim değişim takipteki kredi oranında 0.08 birimlik artışa yol açmaktadır. Bankaların kısa vadeli borçlarını karşılayabilme gücünün ve yatırıma yönlendirilecek kaynaklarının artması, kredi hacminin genişlemesine katkı sağlayacaktır. Bu durumun da takipteki kredi miktarını artırması olası bir durum olarak söylenebilir. Çalışmada elde edilen bu bulgulara karşın finansal kaldıraç, net faiz marjı, aktif karlılık oranı ve özsermaye karlılık oranı ile finansal kırılganlık arasında istatistiksel olarak anlamlı herhangi bir ilişkiye rastlanılmamıştır.

\section{Model 2 İçin Analiz Sonuçları}

Çalışmanın bu bölümünde, finansal kırılganlığı temsil eden bir diğer bağımlı değişken olan sermaye yeterlilik rasyosu (SYO)'na etki eden mikro faktörlerin diğer bir deyişle banka içi unsurların belirlenmesine yönelik model 2 için gerçekleştirilen analizler ve elde edilen bulgulara yer verilmektedir. Çalışmanın bu kısmında, model 2 için panel bazında yapılan yatay kesit bağımlılığı ve homojenite testleri, panel veri modellerinin tahmini için yapılan testler, değişen varyans ve otokorelasyon testi ve tahmin sonuçlarına ilişkin analiz bulgularına yer verilmiştir. Diğer analizlerde elde edilen ortak bulgular model 1'de verildiği için tekrara düşmemek adına bu bölümde verilmemiştir.

\subsection{Yatay Kesit Bağımlıı̆ı̆ının Test Edilmesi}

Seriler arasında yatay kesit bağımlılı̆ının varlığı, Breusch-Pagan (1980) LM testi, Pesaran (2004) CD ve CDIm testleri veya Pesaran, Ullah ve Yagamata (2008) LMadj testi ile tespit edilebilmektedir. Pesaran (2004) CD testi, yatay kesit boyutunun zaman boyutundan büyük olduğu durumlarda ( $N>T$ ) kullanılmaktadır. Çalışmanın N boyutu T boyutundan büyük olduğu için hem panel için yapılan hem de değişken bazında yapılan yatay kesit bağımlılı̆̆ı testlerinden Pesaran (2004) CD testi sonuçları esas alınmıştır. Analiz sonuçları, Tablo $16^{\prime}$ da gösterilmektedir.

Tablo 16: Panel Bazında Yatay Kesit Bağımlıı̆̆ı Test Sonuçları

\begin{tabular}{|c|c|c|}
\hline CD Testleri & İstatistik & Olasılık Değeri \\
\hline$C D_{l m}(\mathrm{BP}, 1980)$ & 222.178 & 0.055 \\
\hline$C D_{l m}$ (Pesaran, 2004) & 1.651 & 0.049 \\
\hline$C D$ (Pesaran, 2004) & 3.838 & 0.000 \\
\hline$L M_{a d j}(\mathrm{PUY}, 2008)$ & -1.109 & 0.866 \\
\hline
\end{tabular}

$\mathrm{H}_{0}$ : Kesitler arasında bağımlıık yoktur

$\mathrm{H}_{1}$ : Kesitler arasında bağımlılık vardır.

Tablo 16'da yer alan panel bazında yapılan yatay kesit bağımlılı̆̆ (YKB) testlerine ilişkin sonuçlar incelendiğinde, YKB için gerçekleştirilen bütün testlerde olasılık değerinin 0.05 'ten küçük çıktığı tespit edilmiştir. Dolayısıyla sıfır hipotez "kesitler arasında bağımlılık yoktur" reddedilmektedir. Paneli oluşturan kesitler arasında yatay kesit bağımlılığı söz konusudur. 


\subsection{Parametlerde Homojenliğin/Heterojenliğin Test Edilmesi}

Yatay kesit bağımlılığı analizi sonrasında, panel veri analizine geçmeden önce sınanması gereken bir diğer varsayım ise homojenlik varsayımıdır. Pesaran ve Yamagata (2008) delta testleri ile sabit terimin ve eğim katsayılarının her bir banka için homojen mi yoksa heterojen mi olduğu tespit edilebilmektedir. Tablo 8'de model 1 için gerçekleştirilen homojenite analiz sonuçları gösterilmektedir.

Tablo 17: Panel Bazında Pesaran and Yamagata (2008) Homojenite Test Sonuçları

\begin{tabular}{lcccc}
\hline Değişken & Delta_tilde & Olasılık Değ. & Delta_tilde_adj & Olasılık Değ. \\
\hline $\boldsymbol{\alpha}$ (Sabit Terim) & 3.521 & 0.000 & 5.154 & 0.000 \\
$\boldsymbol{\beta}$ FiNKAL & 11.990 & 0.000 & 13.526 & 0.000 \\
$\boldsymbol{\beta}$ BUY & 6.416 & 0.000 & 7.239 & 0.000 \\
$\boldsymbol{\beta}$ LKDT & 4.722 & 0.000 & 5.587 & 0.000 \\
$\beta$ NFM & 3.544 & 0.000 & 4.420 & 0.000 \\
$\beta$ ROA & 2.854 & 0.002 & 3.776 & 0.000 \\
$\beta$ ROE & 3.254 & 0.001 & 4.602 & 0.000 \\
\hline
\end{tabular}

$\mathrm{H}_{0}$ : Homojenlik vardır.

$\mathrm{H}_{1}$ : Homojenlik yoktur.

Sabit terim ve her bir değişkenin eğim katsayılarının homojenliğine ilişkin yapılan delta testi sonucuna göre, tahmin edilecek modele ait delta ve düzeltilmiş delta olasılık değerlerinin 0.05 anlamlılık düzeyinden küçük olduğu için sabit terimin ve eğim katsayılarının homojen olduğunu savunan sıfır hipotezi reddedilmektedir. Yani sabit terimin ve her bir değişkenin eğim katsayılarının heterojen olduğu belirlenmiştir.

\subsection{Panel Veri Modellerinin Tahmini}

Finansal kırılganlığa etki eden mikro faktörleri tespit edebilmek için sabit etkiler modeli, rassal etkiler modeli ve havuzlanmış modelden hangisinin tahminleme için kullanılacağına $F$ testi, Breuch-Pagan LM (1980) ve Honda (1985) testleri ile karar verilmiştir. Bu testlere ilişkin analiz sonuçları Tablo 18'de gösterilmektedir.

Tablo 18: Tahmin Modeli Belirleme Analiz Sonuçları

\begin{tabular}{lcccc}
\hline \multicolumn{1}{c}{ Test } & İsta. & P. Değ. & Hipotez & Karar \\
\hline F-grup_fixed & 16.183 & 0.000 & $\mathrm{H}_{0}$ :Kesit etkisi varken zaman etkisi yoktur. & RED \\
$\begin{array}{l}\text { F-zaman_fixed } \\
\text { F-iki yönlü_fixed }\end{array}$ & 2.396 & 0.006 & $\mathrm{H}_{0}$ :Zaman etkisi varken kesit etkisi yoktur. & RED \\
\hline LM-grup_random & 10.930 & 0.000 & $\mathrm{H}_{0}:$ Kesit ve zaman etkisi yoktur & RED \\
LM-zaman_random & 213.203 & 0.000 & $\mathrm{H}_{0}:$ Kesit etkisi varken zaman etkisi yoktur. & RED \\
LM-iki yönlü_random & 0.055 & 0.813 & $\mathrm{H}_{0}:$ Zaman etkisi varken kesit etkisi yoktur. & REDDEDILEMEZ \\
\hline Honda-grup_random & 213.259 & 0.000 & $\mathrm{H}_{0}:$ Kesit ve zaman etkisi yoktur & RED \\
Honda-zaman_random & -0.514 & 0.000 & $\mathrm{H}_{0}:$ Kesit etkisi varken zaman etkisi yoktur. & RED \\
Honda-iki yönlü_random & 2.029 & 0.406 & $\mathrm{H}_{0}:$ Zaman etkisi varken kesit etkisi yoktur. & REDDEDiLEMEZ \\
\hline Hausman & 1.071 & 0.000 & $\mathrm{H}_{0}:$ Kesit ve zaman etkisi yoktur & RED \\
\hline
\end{tabular}

Tablo 18 'deki $\mathrm{F}$ testi sonuçları incelendiğinde, olasılık değerinin kritik değerlerinin altında olduğu belirlenmiş ve sıfır hipotezleri reddedilmiştir. Dolayısıyla modelin havuzlanmış model 
yerine sabit etkiler modeli ile tahmin edilmesi daha etkindir. Ayrıca grup ve zaman etkilerinin varlığına ilişkin test istatistikleri değerlendirildiğinde, tahmin edilecek modelde hem zaman etkisinin hem de kesit etkisinin olduğu yani iki yönlü bir etkinin varlığı tespit edilmiştir.

Tahmin modeli için havuzlanmış model ile rassal etkiler modeli arasından hangisinin daha etkin olduğunu belirleyebilmek amacıyla Breuch-Pagan LM (1980) ve Honda (1985) testleri uygulanmıştır. Analiz sonuçlarına göre, her iki test için de olasılık değeri kritik değerin altında olduğu için rassal etkiler modelinin havuzlanmış modele göre etkinliği ortaya koyulmuştur. Grup ve zaman etkilerinin varlığına ilişkin test istatistikleri değerlendirildiğinde, tahmin edilecek modelde kesit etkisinin olduğu buna karşın zaman etkisinin olmadığı belirlenmiştir. Hausman testi için olasılık değeri incelendiğinde, olasılık değerinin kritik değerden küçük olduğu görülmektedir. Dolayısıyla, sabit etkiler modeli esas alınarak within tahmincisi kullanılarak tahminlemenin yapılmasının daha etkin sonuçlara ulaşılabilmesi için gerekli olduğu belirlenmiştir.

Çalışmada incelenen dönem ve bankalar dikkate alındığında, veri setinin belirli bir gruba ve belirli bir döneme ait olduğu görülmektedir. Model tahminlemesinin hangi model ile yapılması gerektiğine ilişkin analiz sonuçları doğrultusunda çalışmada, model 2 için sabit etkiler modeli esas alınarak en küçük kareler yöntemi (within estimator) kullanılarak tahminleme yapılmıştır.

\subsection{Değişen Varyans ve Otokorelasyonun Test Edilmesi}

Model 1'de olduğu gibi Model 2'de de değişen varyans varsayımı, Breusch-Pagan-Godfrey Heteroscedasticity LM testi ile incelenirken; otokorelasyon varsayımı ise Baltagi ve Li (1991), Born ve Bretuing (2016) ve Bhargava, Franzini ve Narendranathan (1982)'ın Durbin-Watson testleri ile incelenmiştir. İki yönlün sabit etkiler modeli esas alınarak hesaplanmış değişen varyans ve otokorelasyon test istatistikleri Tablo 19'da gösterilmektedir.

Tablo 19: Değişen Varyans ve Otokorelasyon Test Sonuçları

\begin{tabular}{lcc}
\hline Değişen Varyans & istatistik & Olasılık Değeri \\
\hline Breusch-Pagan-Godfrey LMh_fixed & 205.2911 & 0.000000 \\
\hline $\mathrm{H}_{0}:$ Değişen Varyans yoktur & & \\
$\mathrm{H}_{1}$ : Değişen Varyans vardır & & \\
\hline Otokorelasyon & 50.54459 & 0.000000 \\
\hline Baltagi ve Li (1991) LMp-stat & & \\
\hline $\mathrm{H}_{0}:$ Otokorelasyon yoktur & 71.98419 & 0.000000 \\
$\mathrm{H}_{1}:$ Otokorelasyon vardır & & \\
\hline Born ve Bretuing (2016) LMp*-stat & & \\
\hline $\mathrm{H}_{0}:$ Otokorelasyon yoktur & 0.770883 & \\
$\mathrm{H}_{1}:$ Otokorelasyon vardır & & \\
\hline Durbin-Watson & & \\
\hline $\mathrm{H}_{0}:$ Otokorelasyon yoktur & & \\
$\mathrm{H}_{1}:$ Otokorelasyon vardır & & \\
\hline
\end{tabular}

İki yönlü sabit etkiler modeli esas alınarak hesaplanmış değişen varyans ve otokorelasyon değerleri incelendiğinde, Breusch-Pagan-Godfrey LM olasılık değerinin, 0.05 kritik değerinden küçük olduğu tespit edilmiş ve sıfır hipotezi reddedilmiştir. Panelde değişen varyans sorunu söz konusudur. Otokorelasyon testlerine ilişkin sonuçlar değerlendirildiğinde, Baltagi ve Li (1991) LM ve Born ve Bretuing LM (2016) test olasılık değerleri, kritik değerin altındadır ve sıfır hipotezi reddedilmektedir. Panelde otokorelasyon sorunu mevcuttur. 280 gözlem sayısı için DurbinWatson $d$ testi tablosunda $d$ istatistiğinin $d L$ (alt) sınır değeri 1.9303 ve dU (üst) sınır değeri 1.9390 olarak tespit edilmiştir (Bhargava vd., 1982: 537). Durbin-Watson test istatistik değerinin 0.7708 olduğu görülmektedir $(0<\mathrm{d}<\mathrm{dL})$. Bu değerlere göre tahmin edilen modele ilişkin 
Durbin-Watson değerleri otokorelasyonun olduğu bölgeye tekabül ettiği için otokorelasyon olduğuna karar verilmiştir.

\subsection{Tahmin Sonuçları}

Finansal kırılganlığın sermaye yeterlilik rasyosu ile temsil edildiği model 2'de, finansal kırılganlığa etki eden mikro faktörler tespit edilmeye çalışılmıştır. Model 2'de değişen varyans ve otokorelasyon sorunlarının varlığı doğrultusunda bu sorunları dikkate alan ve çözen Beck ve Katz (1995) tarafından geliştirilen Period SUR (PCSE) yöntemi ile panel standart hataların düzeltilmesi yoluyla tahminleme gerçekleştirilmiştir. Tahmin sonuçları, Tablo 20 'de sunulmaktadır.

Tablo 20: Tahmin Sonuçları

\begin{tabular}{|c|c|c|c|c|}
\hline Bağımlı Değişken & & Yöntem & & Örneklem \\
\hline SYO & \multicolumn{3}{|c|}{$\begin{array}{l}\text { Enküçük Kareler Yöntemi } \\
\text { Period SUR (PCSE) standard errors \& covariance (d.f. corrected) }\end{array}$} & $2002-2015$ \\
\hline Açıklayıcı Değişken & Katsayı & Standart Hata & t-İstatistiği & Olasılık \\
\hline BUY & 5.827454 & 3.472135 & $1.678349^{*}$ & 0.0947 \\
\hline FIKD & -21.31498 & 9.942509 & $-2.143824^{* *}$ & 0.0331 \\
\hline LKDT & -0.946754 & 0.950328 & -0.996239 & 0.3202 \\
\hline NFM & 260.8706 & 64.58173 & $4.039387^{* * *}$ & 0.0001 \\
\hline ROA & 295.7944 & 150.0225 & $1.971667^{* *}$ & 0.0499 \\
\hline ROE & -25.50668 & 12.61415 & $-2.022069^{* *}$ & 0.0444 \\
\hline C & 8.431916 & 8.349673 & 1.009850 & 0.3137 \\
\hline & \multicolumn{4}{|c|}{ Period Fixed (Dummy Variables) } \\
\hline & R-squared & 0.803524 & Mean dependent var & 24.20262 \\
\hline & Adjusted R-squared & 0.770778 & S.D. dependent var & 18.24137 \\
\hline & S.E. of regression & 8.733438 & Akaike info criterion & 7.306499 \\
\hline & Sum squared resid & 16932.59 & Schwarz criterion & 7.826906 \\
\hline & Log likelihood & -911.8448 & Hannan-Quinn criter. & 7.515709 \\
\hline & F-statistic & 24.53813 & Durbin-Watson stat & 0.831658 \\
\hline & Prob(F-statistic) & 0.000000 & & \\
\hline \multicolumn{5}{|c|}{$\begin{array}{l}\text { Tabloda; Sermaye Yeterlilik Oranı (SYO), Finansal Kaldıraç Oranı (FIKD), Banka Büyüklüğü (BUY), Net Faiz Marjı } \\
\text { (NFM), Likidite Oranı (LKDT), Aktif Karlıık Oranı (ROA) ve Özsermaye Karlıı̆ğı (ROE) ile gösterilmektedir. }\end{array}$} \\
\hline
\end{tabular}

Model 2 için tahmin sonuçlarının yer aldığı Tablo 20'deki bulgular incelendiğinde, modelin bir bütün olarak anlamlılığını ifade eden $\mathrm{f}$ istatistik olasılık değerinin $\% 99$ güven düzeyinde anlamlı olduğu ve açıklayıcı değişkenlerin bağımlı değişkendeki değişimin $\% 80$ 'ini $\left(R^{2}\right)$ açıkladığı tespit edilmiştir. Model 2'de finansal kaldıraç, net faiz marjı, aktif karlılık oranı ve özsermaye oranı arasında istatistiksel olarak anlamlı sonuçlar elde edilmiştir. Finansal kaldıraç oranındaki bir birim değişim sermaye yeterlilik rasyosunda 21.31 birimlik azalışa neden olmaktadır. Bankalarda mevduat dışı yabancı kaynak kullanımı arttıkça verilen krediler karşılığında ayrılması gereken asgari sermaye yeterliliği için ihtiyaç duyulan kaynak miktarı azalmaktadır. Net faiz marjındaki bir birim değişim ise sermaye yeterlilik rasyosunda 260.87 birimlik artışa neden olmaktadır. Bankaların faiz gelirlerinin artması daha fazla kredi verilmesine yol açabilmekte ve bu durum da tahsis edilen krediler için ayrılan sermayenin de artmasına sebep olmaktadır. Aktif karlıık oranındaki bir birim değişim sermaye yeterlilik rasyosunda 295.79 birimlik artışa yol açarken; özsermaye karlılığındaki bir birim değişim ise sermaye yeterlilik rasyosunda 25.50 birimlik azalışa neden olmaktadır. Bankaların en önemli aktif kalemi konumunda olan krediler kaleminden elde edilen kazancın artması kredi hacminde genişlemeye ve dolayısıyla sermaye yeterlilik rasyosu- 
nun da artmasına yol açabilmektedir. Özsermaye karlılığındaki değişimin sermaye yeterlilik rasyosunu düşürmesini ise daha az yabancı kaynak yani mevduat toplanması ile kredi hacminin daralarak daha düşük seviyede sermaye yeterliliğinin gerçekleşmesine bağlamak mümkündür. Model 2'de elde edilen bu bulgulara karşın likidite oranı ile sermaye yeterlilik oranı arasında istatistiksel olarak anlamlı herhangi bir ilişkiye rastlanılmamıştır.

\section{Sonuç ve Öneriler}

Çalışmada, Türkiye bankacılık sektöründe 2002-2015 yılları arasında devamlı olarak faaliyet gösteren bankaların finansal kırılganlıklarına etki eden mikro faktörleri belirlemek amaçlanmıştır. Finansal kırılganlığın göstergesi olarak takipteki kredi oranı ve sermaye yeterlilik rasyosu esas alınmıştır. Mikro faktörler olarak ise aktif karlılık oranı, özsermaye karlılığı, likidite oranı, banka büyüklüğü, finansal kaldıraç ve net faiz marjı esas alınmıştır. Finansal kırılganlık ile mikro faktörler arasındaki ilişki, panel veri analizi ile incelenmiştir. Panel veri analizi kapsamında öncelikle bağımsız değişkenler arasında çoklu doğrusal bağlantı sorununun olup olmadığına yönelik olarak spearman korelasyon analizi ve varyans şişirme testi gerçekleştirilmiştir. Sonrasında ise paneli oluşturan yatay kesitler (bankalar) arasındaki bağımlılık, panel ve değişken bazında Breusch-Pagan (1980) (Lagrange Multiplier-LM) ve Pesaran (2004) (Cross-section Dependence$\mathrm{CD})$ testleriyle incelenmiştir. Değişkenlerin katsayılarının yatay kesitten yatay kesite değişip değişmediği ise Pesaran ve Yamagata (2008) tarafından geliştirilen Homogeneity Testi ile araştırılmıştır. Serilere ilişkin durağanlık, yatay kesit bağımlıı̆ı̆ını dikkate alan Bai ve Ng (2004) PANiC ikinci nesil birim kök testi ve homojenliği/heterojenliği dikkate alan Im, Pesaran ve Shin (2003) IPS ve Levin, Lin ve Chu (2002) birinci nesil testler ile analiz edilmiştir. Tahmin modelinin seçimi için ise F testi, Breuch-Pagan LM (1980), Honda (1985) testleri ve Hausman (1978) testi uygulanmıştır. Hata terimlerinin varyanslarının tüm gözlemler için aynı olmama sorununu ifade eden değişen varyans sorununun varlığı, Breusch-Pagan-Godfrey Heteroscedasticity LM ile incelenirken otokorelasyon ise Baltagi ve Li (1991), Born ve Bretuing (2016) ve Bhargava, Franzini ve Narendranathan (1982)' In Durbin-Watson testleri ile incelenmektedir. Model tahminlemesi ise Beck ve Katz (1995) tarafından geliştirilen panel standart hataları düzelten, Period SUR (PCSE) yöntemi kullanılarak gerçekleştirilmiştir. Çalışmada, finansal kırılganlığı temsil eden değişkenler doğrultusunda iki farklı model oluşturulmuştur. Takipteki kredi oranı esas alınarak oluşturulan model 1' de elde edilen sonuçlar incelendiğinde, banka büyüklügü ile finansal kırılganlık arasında istatistiksel olarak anlamlı ve negatif ilişki tespit edilirken; likidite oranı ile istatistiksel olarak anlamlı ve pozitif ilişki tespit edilmiştir. Sermaye yeterlilik rasyosu esas alınarak oluşturulan model 2'de ise finansal kaldıraç ve özsermaye karlılığı ile finansal kırılganlık arasında istatistiksel olarak anlamlı ve negatif ilişki belirlenirken; net faiz marjı ve aktif karlılık oranı ile finansal kırıganlık arasında ise istatistiksel olarak anlamlı ve pozitif ilişki belirlenmiştir.

Bu çalışma ile bankacılık sektörünün kırılgan bir yapıya sahip olup olmadığı ve bu kırılganlığa hangi faktörlerin sebep olduğu tespit edilmeye çalışılmıştır. Genel olarak elde edilen sonuçlar, bankacılık sektörünün kırılgan bir yapıya sahip olmadığı ve incelenen dönem içerisinde gerçekleşen finansal krizlerin olumsuz sonuçları doğrultusunda daha ihtiyatlı davrandığı söylenebilir. Diğer bir ifadeyle, çalışmada bankaların büyüklük, likidite, karlılık ve finansman kararlarına ilişkin elde edilen bulgular, bankaların mali yapılarını güçlendirme ve geçmişten ders çıkarma anlamında daha temkinli ve doğru hareket ettikleri şeklinde değerlendirilebilir.

Bankaların finansal kırılganlıklarını azaltabilmeleri için sahip oldukları likit varlıkları daha etkin kullanmaları, uyguladıkları faiz politikalarına devam etmeleri ve elde edilen faiz gelirleri doğ- 
rultusunda daha yüksek oranda sermaye yeterlilik rasyosuna sahip olmalarının gerektiği düşünülmektedir. Dolayısıyla çalışmada elde edilen bulguların, banka üst düzey yönetimine ve yatırımcılara yol gösterici nitelikte olduğu söylenebilir.

Çalışma, finansal kırılganlığın makro düzeyde sermaye yeterlilik oranı ile mikro düzeyde ise takipteki kredi oranı ile ayrı ayrı ölçülmesi ve finansal kırılganlığa etki ettiği düşünülen bankaya özgü faktörlerin bankaların finansman kararları, likidite, faiz politikaları, karlılık durumları ve banka büyüklüğü esas alınarak belirlenmesi açısından özgün bir değere sahip olmakta ve ulusal literatüre katkı sağlamaktadır. Çalışma, inceleme döneminin genişletilmesi, farklı ülkelerin bankacılık sektörleri ile kıyaslama yapılması ve ekonometrik yöntemlerin farklılaştırılması suretiyle konuya ilişkin yapılacak sonraki çalışmalarca geliştirilebileceği düşünülmektedir. 


\section{Eskişehir Osmangazi Üniversitesi IïB Dergisi}

\section{Kaynaklar}

Ahumada, Antonio; Budnevich, Carlos (2002), Some Measures of Financial Fragility in the Chilean Banking System: An Early Warning Indicators Application, L. Hernandez ve K.S. Hebbel, (Eds.), Banking, Financial Integration and International Crisis içinde, Santiago: Central Bank of Chile, 175-197.

Allen, Franklin; Gale, Douglas (2004), "Financial Fragility, Liquidity And Asset Prices", Journal of the European Economic Association, 2 (6), 1015-1048.

Asteriou, Dimitrios; Hall, Stephen (2007), Applied Econometrics: A Modern Approach Using Eviews and Microfit Revisited Edition, Newyork: Palgrave Macmillan.

Bai, Jushan; Ng, Serena (2004), “A PANIC Attack on Unit Roots and Cointegration”, Econometrica, 72 (4), 1127-1177.

Baltagi, Badi; Li, Qi (1991), “A Joint Test for Serial Correlation and Random Individual Effects”, Statistics and Probability Letters, 11, 277-280.

Bankacılık Düzenleme ve Denetleme Kurumu (2017), İstatistiki Veriler, http://www.bddk.org.tr/WebSitesi/turkce/Istatistiki_Veriler/Istatistiki_Veriler.aspx.

Beck, Nathaniel; Katz, Jonathan (1995), "What To Do (and Not to Do) with Time-Series Cross-Section Data", American Political Science Review, 89 (3), 634-647.

Bhargava, Alok; Franzini, Luisa; Narendranathan, Wiji (1982), "Serial Correlation and the Fixed Effects Model”, The Review of Economic Studies, 49 (4), 533-549.

Born, Benjamin; Breitung, Jörg (2016), "Testing for Serial Correlation in Fixed-Effects Panel Data Models", Econometric Reviews, 35 (7), 1290-1316.

Bostandzic, Denefa (2016), "Bank Fragility and Interconnectedness", World-Finance-Conference.

Breitung, Jörg (2005), "A Parametric approach to the Estimation of Cointegration Vectors in Panel Data", Econometric Reviews, 24 (2), 151-173.

Breuer, Janice Boucher; McNown, Robert; Wallace, Myles (2002), "Series-Specific Unit Root Tests With Panel Data", Oxford Bulletin of Economics and Statistics, 64, 527-546.

Breusch, Trevor; Pagan, Adrian (1979), "A simple Test For Heteroscedasticity And Random Coefficient Variation”, Econometrica, 47, 1287-1294.

Breusch, Trevor; Pagan, Adrian (1980), "The Lagrange Multiplier Test and Its Applications to Model Specification in Econometrics", Review of Economic Studies, 47 (1), 239-253.

Bruno, Oliver; Cartapanis, Andre; Nasica, Eric (2013), “Bank Leverage, Financial Fragility and Prudential Regulation. Bank Leverage, Financial Fragility and Prudential Regulation", Working Paper, No: 14, 1-36.

Choi, In (2001), “Unit Root Tests For Panel Data”, J. Int. Money and Finance, 20, 249-272.

Corsetti, Giancarlo; Pesenti, Paolo; Roubini, Nouriel (2001), "Fundamental Determinants of the Asian Crisis: The Role of Financial Fragility and External Imbalances", In Regional and Global Capital Flows: Macroeconomic Causes and Consequences, University of Chicago Press, NBER-EASE, 10, 11-41.

Egan, Mark; Hortaçsu, Ali; Matvos, Gregor (2017), "Deposit Competition and Financial Fragility: Evidence from the US Banking Sector", American Economic Review, 107 (1), 169-216.

Engle, Robert; Granger, Clive (1987), "Co-Integration and Error Correction: Representation, Estimation, and Testing", Econometrica, 55 (2), 251-276.

Erlat Haluk (2015), Panel Data: A Selectıve Survey, Ankara: Department of Economics Middle East Technical University.

Fielding, David; Rewilak, Johan (2015), “Credit Booms, Financial Fragility And Banking Crises”, Economics Letters, University of Otago Economics Discussion Papers, 1507 (136), 233-236.

Ghosh, Saibal (2010), "Credit Growth, Bank Soundness and Financial Fragility: Evidence from Indian Banking Sector", MPRA Paper, 24715.

Godfrey, Leslie (1978), “Testing For Multiplicative Heteroscedasticity”, Journal of Econometrics, 8, 227-236.

Grabel, llene (1997), Speculation-Led Development in the Third World, Dynamics of Globalization and Development, Recent Economic Thought Series II, Springer US.

Gujarati, Damador (2003), Basic Econometrics, New York: McGraw Hill Book Co. 
Hadri, Kaddour (2000), "Testing For Stationarity İn Heterogeneous Panel Data”, Econometrics Journal, 3 (2), 148-161. Hadri, Kaddour; Kurozumi, Eiji (2012), “A Simple Panel Stationarity Test İn The Presence Of Serial Correlation And A Common Factor", Economics Letters, 115 (1), 31-34.

Hair, Joseph; Anderson, Rolph; Tatham, Rolph; William, Black (1998), Multivariate Data Analysis, New Jersey: PrenticeHall.

Hausman, Jerry (1978), "Specification Tests in Econometrics", Econometrica, 46, 1251-1271.

Honda, Yuzo (1985), "Testing the Error Components Model with Non-Normal Disturbances", Review of Economic Studies, 52, 681-690.

Iftikhar, Syed Faizan (2015), "Financial Reforms and Financial Fragility: A Panel Data Analysis", Int. J. Financial Studies, 3, 84-101.

Im, Kyung; Pesaran, Hashem; Shin, Yongcheol (2003), "Testing For Unit Roots in Heterogeneous Panels", Journal of Econometrics, 115, 53-74.

Kao, Chihwa (1999), "Spurious Regression and Residual-Based Tests For Cointegration in Panel Data”, Journal of Econometrics, 90 (1), 1-44.

Kinda, Tidiane; Mlachila, Montfort; Ouedraogo, Rasmane (2016), “Commodity Price Shocks and Financial Sector Fragility", IMF Working Papers.

Klomp, Jeroen; De Haan, Jakob (2015), “Bank Regulation And Financial Fragility İ Developing Countries: Does Bank Structure Matter?", Review of Development Finance, 5, 82-90.

Korkmaz, Özge; Erer, Deniz; Erer, Elif (2016), “Bankacılık Sektöründe Yoğunlaşma İle Finansal Kırılganlık Arasındaki İlişki: Türkiye Örneği (2007-2014)”, Muhasebe ve Finansman Dergisi, 69, 127-146.

Kök, Recep; İspir, Serdar; Arı, Aydın (2010), "Zengin Ülkelerden Azgelişmiş Ülkelere Kaynak Aktarma mekanizmasının Gerekliliği ve Evrensel Bölüşüm Parametresi üzerine Bir Deneme”, 2. Uluslararası Ekonomi Konferansı, Türkiye Ekonomi Kurumu, Kıbrıs.

Lagunoff, Roger; Schreft, Stacey (2001), “A Model of Financial Fragility”, Journal of Economic Theory, 99, 220-264.

Levin, Andrew; Lin, Chien; Chu, Chia Shang James (2002), “Unit Root Tests In Panel Data: Asymptotic And Finite-Sample Properties", Journal of Econometrics, 108, 1-24.

Maddala, Gangadharrao Soundalyarao; Wu, Shaowen (1999), “A Comparative Study of Unit Root Tests with Panel Data and a New Simple Test", Oxford Bulletin of Economics and Statistics, 61 (S1), 631-652.

Pedroni, Peter (1999), "Critical Values for Cointegration Tests in Heterogeneous Panels With Multiple Regressors", Oxford Bull. Econ. Stat, 61 (Special Issue), 653-670.

Pedroni, Peter (2000), "Fully-Modified OLS for Heterogeneous Cointegrated Panels”, Advances in Econometrics, 15, 93130.

Pedroni, Peter (2001), "Purchasing Power Parity Tests in Cointegrated Panels", Review of Economics and Statistics, 83, 727-731.

Penas, Maria Fabiana; Tümer Alkan, Günseli (2010), “Bank Disclosure and Market Assessment of Financial Fragility: Evidence from Turkish Banks' Equity Prices”, J Financ Serv Res, 37, 159-178.

Pesaran, Hashem (2004), “General Diagnostic Tests For Cross Section Dependence in Panels", Cambridge Working Papers in Economics Working Paper, 435.

Pesaran, Hashem; Yamagata, Takashi (2008), "Testing Slope Homogeneity İn Large Panels", Journal of econometrics, 142, 50-93.

Pesaran, Hashem (2007), “A Simple Panel Unit Root Test In The Presence Of Cross Section Dependence”, Journal of Applied Econometrics, 22 (2), 265-312.

Rojas-Suarez, Liliana (1998), Early Warning Indicators of Banking Crises: What Works for Developing Countries?, InterAmerican Development Bank.

Smith Vanessa; Leybourne, Stephen; Kim, Tae Hwan; Newbold, Paul (2004), “More powerful Panel Data Unit Root Tests With An Application To Mean Reversion İn Real Exchange Rates", Journal of Applied Econometrics, 19, 147-170.

Stavarek, Daniel (2005), "Linkages between Stock Prices and Exchange Rates in the EU and the United States", Czech Journal of Economics and Finance, 55 (3-4), 141-161.

Tabachnick, Barbara; Fidell, Linda (2001), Using multivariate statistics. Boston: Allyn and Bacon.

Türkiye Bankalar Birliği (2017), Banka ve Sektör Bilgileri, www.tbb.org.tr. 


\section{Eskişehir Osmangazi Üniversitesi iiBF Dergisi}

Zwet, Annemarie; Swank, Job (2000), Financial Fragility And Macroeconomic Performance, DNB Staff Reports, 52, 123. 